Article

\title{
CSR Maturity in Polish Listed Companies: A Qualitative Diagnosis Based on a Progression Model
}

\author{
Anna Witek-Crabb \\ Department of Strategic Management, Wroclaw University of Economics, 53-345 Wroclaw, Poland; \\ Anna.Witek@ue.wroc.pl; Tel.: +48-713680209
}

Received: 25 February 2019; Accepted: 19 March 2019; Published: 22 March 2019

\begin{abstract}
Transformation from a centrally planned economy to a market economy in 1989 created new challenges for the enterprises in Poland. Free market brought economic liberty, but also the need to take responsibility for the business' impact on the environment. The last 20 years have brought intensive development of Corporate Social Responsibility (CSR) in Polish conditions: The institutional context supporting CSR has improved and so did the implementation of the CSR by the business. Intensive growth of CSR practices demands a reflection on the effectiveness of the implementation. This study's contribution is a comprehensive diagnosis of CSR maturity of the enterprises in Poland using a conceptual CSR maturity model. The model is comprised of three perspectives: CSR process maturity, CSR formal maturity and CSR developmental maturity. CSR practices of 93 listed companies from nine industries were studied in 2016-2017. A qualitative content analysis of the enterprises websites was used as the method of study. The main finding was that the level of CSR practices of the enterprises in Poland is still rather low. Forty-seven percent of the enterprises implement incidental CSR, 30\% tactical CSR and 23\% apply strategic CSR. CSR maturity level is company size- and industry-dependent.
\end{abstract}

Keywords: CSR; CSR maturity; business sustainability; Poland

\section{Introduction}

The history of CSR (Corporate Social Responsibility) in Poland is relatively short. Political changes from a centrally planned economy to a market economy in 1989 created new challenges for Polish businesses. Liberty, however, brought responsibility. Enterprises had to face not only challenges of functioning in the capitalist system, but also taking responsibility for the way they affected their social and environmental surroundings.

The last 20 years have brought intensive CSR growth in Poland. It has been a period when Poland, similar to other Central European countries, has tried to make up for the negligence from before the transformation [1] and to implement the CSR standards of developed countries to be their equal partner regarding sustainability.

There are a few reasons that make CSR in the Polish context an interesting research topic: There has only been a short dynamic history of CSR implementation, significant changes related to the improvement of the CSR institutional environment (legislation, public and non-governmental institutions, CSR standards) and the transformation of managers awareness; and there is the fact that CSR practices in Polish enterprises have not been extensively studied. There are no review studies diagnosing the maturity and advancement of CSR practices of enterprises in Poland. There is only fragmented research, concerning particular aspects of CSR, such as the level of CSR disclosure [2-7], stakeholder reporting standards [8] or the institutional environment of CSR [9]. This study's contribution is the complex diagnosis of CSR conditions in Poland. It could be the basis for designing 
actions to help propagate this concept and improve the quality and efficiency of initiatives undertaken by enterprises.

The purpose of the research was to diagnose the CSR maturity of enterprises in Poland. In particular, answers to the following research questions have been sought:

1. Which level of CSR maturity—incidental, tactical or strategic —is presented by the companies in Poland covered by the study?

2. What is the distribution of CSR maturity in the studied population and does the CSR maturity depend on a company's size and industry?

3. What is the level of CSR process maturity, CSR formal maturity and CSR developmental maturity, and what practices do the studied enterprises present?

Theoretical assumptions concerning the measurement and interpretation of CSR practices have been adopted to enable CSR maturity diagnosis. A CSR maturity model was proposed, based on progression models of CSR on the one side [10-24], and an organizational maturity concept [25] derived from the capability maturity model on the other side [26-28]. The CSR maturity model framework consisted of three perspectives: the CSR process maturity, the CSR formal maturity and the CSR developmental maturity, referring to the processes, values and underlying assumptions of the CSR activities of enterprises [29].

The CSR practices of 93 companies of different sizes, listed on the Warsaw Stock Exchange and representing nine sectors were studied (Appendix A). A qualitative content analysis of documents present on the enterprises' websites was used as the method of study.

The research presented is of a theoretical and practical nature. In the theoretical part, deliberations on internal and external CSR determinants are presented and CSR progression models are considered in order to develop a conceptual CSR maturity model. In the practical part, a historical and institutional context for CSR in Poland are presented and CSR maturity diagnosis of the research sample is performed, applying a conceptual CSR maturity model. Conclusions about the maturity of CSR in enterprises in Poland are drawn, together with the recommendations for further dissemination of the concept in companies of different types.

\section{Recent History of CSR in Poland-Institutional Context}

After several decades of a post-war centrally-planned economy, the political changes at the turn of the 1980s and 1990s brought capitalism and a market economy to Poland. It was accompanied by the growth of the long-restrained spirit of entrepreneurship and the necessity to educate managerial staff capable of functioning in a free market environment. The economic and social priorities were not always balanced in the first years after the transformation. The rapid political, economic and social transformation contributed to significant economic growth, but generated social costs like unemployment, poverty and debarment [30,31].

The concept of CSR appeared in Poland at the turn of the millennium. In 1999, the Business Ethic Center had been brought to life at Kozminski University, and in 2001, Forum Odpowiedzialnego Biznesu (the Responsible Business Forum) was established-a leading non-governmental organization promoting socially responsible business and publishing an annual report titled "The Responsible Business in Poland. Good practices" since 2002. In 1999, the Council of Ministers adopted the document "Poland 2025-Long-term Sustainable Development Strategy" [32], incorporating Poland in the global movement inspired by Agenda 21 and the declaration from the 1992 Rio de Janeiro Climate Summit.

The first significant CSR initiatives among entrepreneurs also appeared at that time-Elektrownia Opole implemented the SA8000 standard in 2001, and ABB launched a formal dialog procedure with their stakeholders in 2002. At the same time, in 2002, the Warsaw Stock Exchange adopted the first code "Good practices in publicly listed companies" where recommended corporate governance principles were referred to. 
This activity coincided with a CSR European campaign-in 2001 the Green Book was established-a document published by the European Commission, stating that "CSR is a concept whereby companies integrate social and environmental concerns into their business operations and into their interactions with their stakeholders on a voluntary basis" [33]—a definition most widely used today.

Poland developed CSR-supporting institutions and popularized social responsibility practices very quickly. In the opinion of the UNDP, the Polish economy has undergone a fast maturation process. In the case of developed markets, CSR development took whole decades, whilst in Poland, it was a matter of several years [34].

The first years of CSR in Poland can be divided into the following periods:

- The first stage of CSR development in Poland (1989-1999) can be described as a phase of silence and lack of interest [34].

- In the second stage (2000-2002), CSR raised dislike and sometimes even opposition from many business leaders and economic columnists, overwhelmed by the idea of "the invisible hand of the market" as a cure-all therapy [34].

- The third stage (2003-2004) brought interest in declaring recognition of ethics and social responsibility as a foundation of a company's conduct [34].

- The fourth stage (2004-2005) concerned the development of specific, albeit partial projects, involving certain significant areas of a company's functioning [34].

- The fifth stage (2006-2007) was an attempt to link CSR with other strategies implemented in a company, i.e., communications, personnel, marketing or corporate governance strategy [34].

- The sixth stage (2007-now) is of advanced implementation when managers of large and medium companies try to adapt their activities to standards observed in Western practices [35].

At that time, a dynamic CSR revolution in enterprises was taking place due to the intensification of foreign investments in Poland and the inflow of a different management culture [36,37]. In 2009, the Warsaw Stock Exchange implemented the RESPECT Index-the first index of socially responsible companies in Central and Eastern Europe. In the same year, the Prime Minister appointed an inter-departmental CSR Team, consisting of four work groups. Its aim was to coordinate CSR activities of administration bodies, watching CSR good practices abroad, collecting experiences, and promoting and conducting a dialog with stakeholders [37]. By administrative arrangements, the group was dismissed in 2013, and in 2014 a new CSR Team was appointed by the then Ministry of Economy. It was constituted to be responsible for issues like social innovation, sustainable production and consumption, renewable energy sources and energy efficiency, and CSR for SMEs.

In 2015, Poland became one of 193 signatories of the UN Resolution on the 2030 Agenda for Sustainable Development which established 17 goals of sustainable development and 169 targets. In July 2018, for the first time Poland presented its progress in implementing the Sustainable Development Goals under a Voluntary National Review [38].

Adopting the 2030 Agenda in September 2015 coincided with the work on a medium-term country strategy in Poland-the Strategy for Responsible Development [39] and its implementation. The new development model for Poland presented in the Strategy is convergent with the 2030 Agenda on the level of goals, priorities and indicators.

In January 2018, after the reconstruction of the government, the coordination of the implementation of the 2030 Agenda in the country was entrusted to the Ministry of Entrepreneurship and Technology.

In the last years, Polish law has significantly changed to comply with EU standards for CSR and sustainability. The most recent changes concern the obligation of nonfinancial data disclosure. At the end of 2016, the Polish Accounting Act was amended [40] to incorporate guidelines of the EU Directive 2014/95/EU [41]. Since January 2017, this directive imposes the obligation to disclose information on environmental, social, employment, human rights, anti-corruption activity and diversity policy issues 
on 6000 large public interest entities in Europe (including approx. 300 in Poland). Poland does not have a long tradition of reporting social responsibility, so for many Polish companies the EU directive means the necessity to rapidly implement routines they have never used. Therefore, Poland was one of the countries initially opposing this EU legislation process.

The institutional environment in Poland is increasingly favorable for CSR. The EU legislative initiatives create a legal climate for implementing changes in EU member states; the growing CSR awareness fosters the improvement of standards in individual industries and there is a noticeable support of public institutions for CSR behavior. However, the actual question regarding the level of CSR implementation in enterprises remains open. Government reports are usually more optimistic than the reports of nonprofit or academic organizations. The conclusions of the "Implementation of the Sustainable Development Goals in Poland" [38] report, adopted by the Council of Ministers in 2018 , is positive. It indicates that Poland improves its practices in terms of all the goals of the 2030 Agenda and does not deviate from the European standards.

At the same time, however, other non-governmental cross-sectional studies show much a more pessimistic image of the situation. Although Directive 2014/95/EU [41] came into force, non-financial reporting of enterprises in Poland is deficient or nonexistent. The 2016 study, preceding the enforcement of the directive, as well as the 2017 study, after the law enforcement, are not optimistic. Matuszak and Różańska [2] claim that the 2016 extent and quality of voluntary CSR disclosure among Polish public interest entities did not meet the new requirements introduced by Directive 2014/95/EU from 2017. Research performed by Ernst \& Young [42] in 2017 on 140 companies obliged to ESG reporting led to the conclusion that nearly half of the companies did not report or barely reported in all the areas covered by the obligation. The analysis of data contained in the GRI Database shows that since 2013 the number of Polish companies publishing reports in compliance with GRI standards has stabilized. Until 2012, a strong quantitative growth was observed, whereas after 2013 the number of Polish companies publishing GRI reports has remained at 43-45 [43].

The analysis of changes in the implementation of CSR in Poland from the institutional perspective between 2007 [34] and 2014 [9] indicates that Poland has made only insignificant progress in areas like the legal and political environment, civil society context, reporting, and CSR standards. Although more than $65 \%$ of 227 Polish companies covered by the research by the CentrumCSR.pl Foundation declare commitment to CSR, these declarations are rather general and not supported by verifiable data [44], and CSR is primarily implemented by large international companies [1].

\section{Developing CSR in Enterprises}

Efficient implementation of CSR in companies requires knowledge of two issues: the conditions that favor the implementation of CSR (CSR determinants) and the progression models for CSR development.

On the one hand, there are certain economic, cultural and organizational determinants conductive of the implementation of CSR. They can be seen as a lever increasing chances for an efficient outcome. On the other hand, there are certain CSR models describing how to improve practices, leading to more mature CSR forms. CSR is an umbrella term referring to a wide spectrum of actions towards company's stakeholders. Implementing additional CSR activities does not always mean a more mature approach towards this concept, hence the understanding of CSR progression models is important for managers.

Both issues are presented below. A literature review of determinants which drive CSR behavior in companies and support enterprises' CSR commitment has been proposed. Also, a brief summary of selected progression models of CSR was presented, which then led to a proposition of a conceptual model of CSR maturity. 


\subsection{CSR Determinants}

The decision of whether and how to implement the CSR concept depends on many factors. CSR determinants can be divided into external and internal ones, depending on whether they are embedded inside or outside the company (Figure 1).

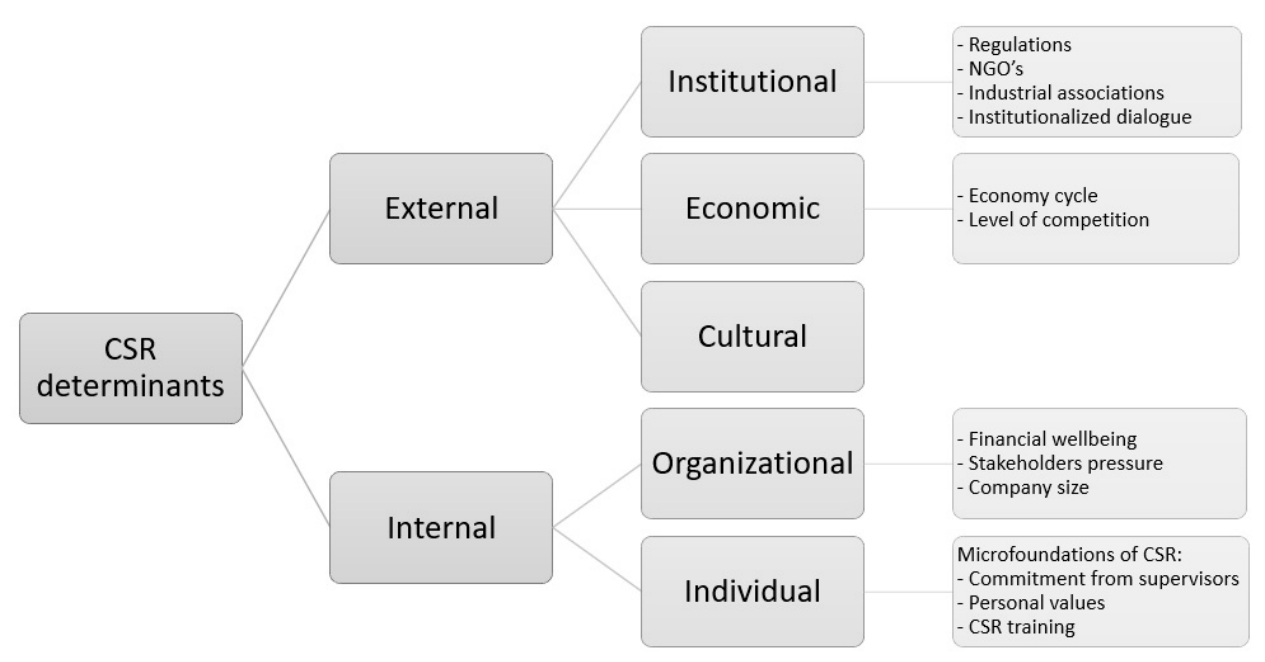

Figure 1. CSR determinants. Source: Own work.

Among the external determinants, the institutional [45,46] economic [45] and cultural [47-50] contexts play a significant role. There is a higher probability that enterprises will commit themselves to socially responsible actions, if the institutional context is supportive. Especially, if there are legal regulations in place referring to CSR behaviors on the national level as well as resulting from self-regulation in particular industries. Industry membership has been confirmed many times as a factor diverting enterprises' commitment to CSR activity [51-54]. Sectors commonly recognized as harmful to the environment are more active in this field [55]. The next institutional determinant influencing enterprises' CSR commitment is the activity of nonprofit organizations whose role is to monitor corporate behavior [45]. Also, the companies' participation in industrial associations engaged in institutionalized dialog with stakeholders is an important factor. The presence of both these determinants increases the chance for such a company to take CSR actions [45].

A good economic situation is also an incentive for undertaking socially responsible practices, whereas competition intensity has a twofold influence-if moderate, the chances for CSR increase; if too small or too intense, they decrease [45].

The will to take CSR actions also has a cultural grounding. There are multiple studies showing national differences in the implementation of the social responsibility concept $[47-50,56]$. For example, cultures with high individualism and uncertainty indicators according to Hofstede's dimensions [57] have a positive influence on the firm's CSR commitment [49].

Internal determinants influencing a firms' CSR activity can be divided into organizational and individual. Financial wellbeing is one of the organizational determinants acting as a CSR incentive [45]. However, it should be noted that the relation between an enterprise's financial performance and its level of CSR disclosure is equivocal. Part of the research shows a positive relation of CSR with profitability $[50,58]$ or turnover [3], part shows no relation $[59,60]$, and part shows a negative relation [61].

The extent of CSR activity is also related to the expectations of the closest firm's stakeholders. The stakeholders pressure enhances the chances for a positive firm's commitment to CSR. The level and the nature of CSR commitment will depend not only on the firm's shareholders' approach, but also the parent company's CSR policy (in the case of MNCs) [46] or the expectations of the company's clients regarding a company's sustainability $[62,63]$. According to the research, the level of CSR commitment 
also depends on the pressure of the employees on issues related to employment conditions, safety standards and employment stability [64].

An organizational determinant which is unequivocally related to the level of CSR is a company's size $[50,52-54,58,65,66]$. Numerous studies show that larger firms are more likely to engage in CSR and to report their CSR activity [55,62]. Large firms have a more significant impact on the environment and a more complex network of relations with their stakeholders which increases the pressure on taking CSR actions and the need for dialogue $[54,58,67]$.

Managers' psychological microfoundations are the individual determinants influencing an enterprises' CSR commitment. For the last 5 years, a significant growth of interest in studies aimed at finding individual CSR drivers and how CSR affects individuals has been noted [68-71]. These studies can be included in the person-centric view of CSR [72]. The most important determinants influencing individual CSR choices in managers are: the CSR commitment from the supervisors, personal values and CSR training. The research shows that CSR commitment from the supervisors increases the probability that the employees will also commit themselves to such actions [73,74]. For example, it has been observed that companies taking CSR actions due to institutional pressures, but without the management board's CSR commitment, often practice a so called "decoupled CSR", which has no connection with the firm's daily routines and its business case [75]. Another determinant driving the CSR behavior of individuals is its values. Personal values and beliefs and their consistency with company values are important predictors of CSR actions [76]. The CSR knowledge gathered through trainings, participation in conferences or reading CSR guidelines also drives CSR behavior in individuals $[75,77]$.

\subsection{Progression Models of CSR}

Progression models of CSR are conceptual frameworks that indicate the manner in which a company can improve its practices concerning CSR through structuring them from less to more advanced. To create a tool for measuring the maturity of CSR of enterprises in Poland, 10 available progression models of CSR proposed by previous research in the last 40 years have been analyzed [78]. There are many models that display a step-wise approach to the development of CSR in enterprises; however, these models are often divergent or contradictory. The manner of progression contained in these models is dependent on the adopted paradigms advocated by their authors. The same CSR practices are interpreted as imperfect in one paradigm and, at the same time, viewed as mature in another paradigm. Examples of such controversial practices may include CSR focused on a company's self-interest or corporate philanthropy. There are models that will place these manifestations of CSR at the two extremities of the CSR maturity continuum, where some models would interpret philanthropy as the initial stage of CSR development in a company [14-16,22,23], while others would rather treat it as the superior form of implementation of this concept [13,20].

To categorise the progression CSR models, a division into two groups of models, based on different paradigms, has been introduced. The first group consists of evolutionary CSR models oriented towards moral values. In this group, the improvement of CSR goes hand-in-hand with a progression towards morally-motivated, altruistic activities as well as activities aimed at a culture supporting all creatures $[17,79,80]$. In this perspective, philanthropy qualifies as the purest form of corporate responsibility $[81,82]$. A company improves its CSR by moving across the continuum whose start can be described as an amoral approach [20], which is characterised by an unsupportive corporate culture [83] and a focus on the company's self-regarding interest. The other end of this continuum is a moral approach that is characterised by a supportive, other-regarding culture and a willingness to help [84].

The second group consists of progression CSR models oriented towards economic value. In this group, the improvement of CSR takes place through increasing efficiency and professionalism, which should eventually lead to the creation of economic added value for all stakeholders [14-16]. These models display a progression from accidental, chaotic and rather inefficient actions to strategic and 
well-thought out activities of high economic efficiency for a wide range of stakeholders and with a high potential of introducing social change $[18,19,24]$. These models emerged from studies looking for correlation between CSR and corporate financial performance, thus allowing the introduction of CSR to the mainstream of management [64,85-91].

The two orders ruling the progression of CSR practices, the order of moral value and the order of economic value, represent a complimentary approach. The attempt to design a CSR maturity model is based on the assumption that it is possible to simultaneously fulfil moral standards and act in an effective, stable and productive way in doing so.

\section{Materials and Methods}

\subsection{CSR Maturity-Conceptual Model}

In order to assess the CSR maturity of the enterprises in Poland and to answer the research questions, a CSR maturity model was proposed.

The framework of the CSR maturity model was inspired by the model of an organizational culture by Edward Schein [29]. This model, often presented as an iceberg or a pyramid, explains organizational behavior in a multi-dimensional way, referring to three levels of analysis. The first level of analysis refers to artifacts such as visible organizational structures and processes; the second level refers to espoused values present in strategies, goals and philosophies; and the third level refers to basic underlying assumptions which are unconscious beliefs about the nature of reality, relationship to the environment and human nature [92]. Artifacts are explained by values, which are grounded in people's underlying assumptions. The understanding of the dynamics and the relation between the three levels gives a more complex explanation of organizational behavior.

The CSR maturity model refers to the three levels determined by Schein. The multitude of perspectives is to ensure a more complex image of CSR activities in a company (Figure 2). In the model proposed, not only the CSR actions are evaluated, but also the presence of CSR commitment in the company's strategy, values and beliefs is considered.

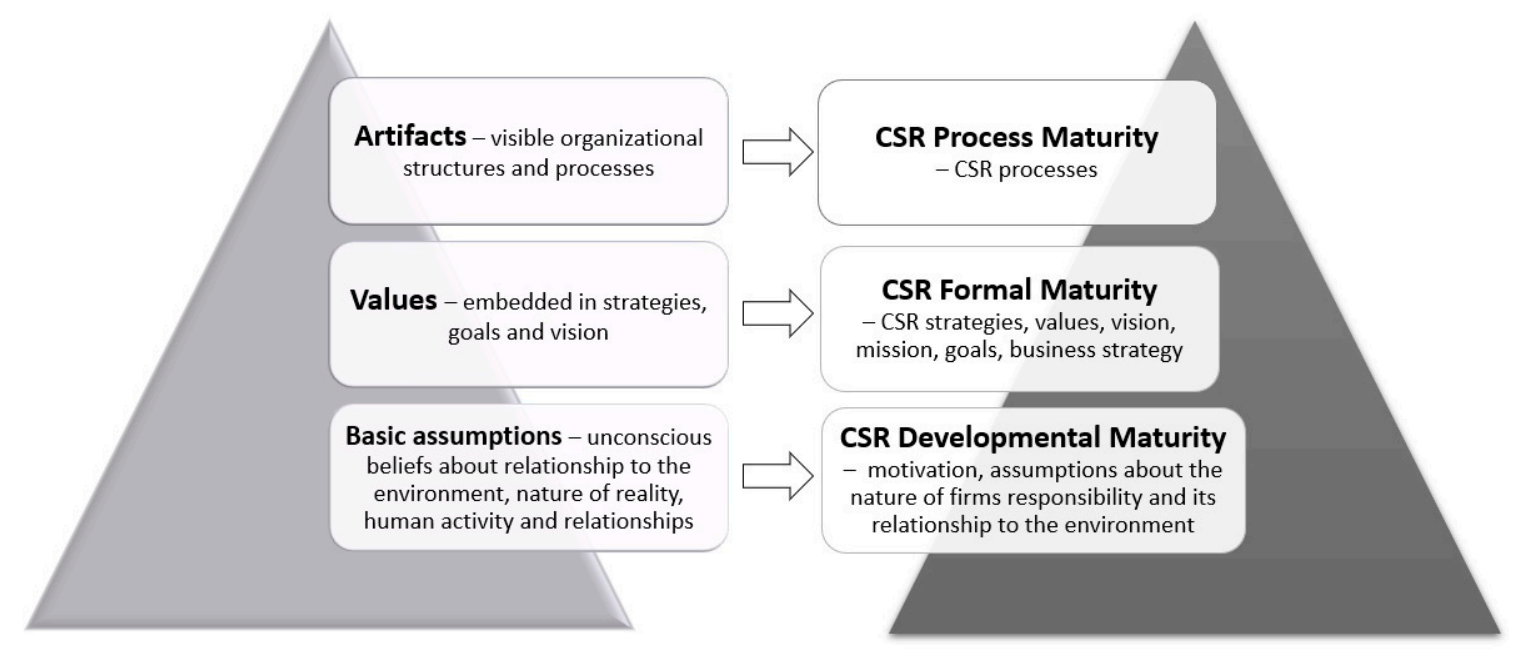

Figure 2. CSR maturity model-triple perspective. Source: Own work.

To measure the maturity of CSR in enterprises, the following assumptions were made:

- The CSR maturity can be analyzed at three levels: the level of artifacts, of espoused values and of basic assumption (Figure 2).

- Artifacts will refer to visible processes through which the enterprise conducts CSR activity. The CSR process maturity will be the measured construct. 
- Espoused values will refer to CSR commitments as present in companies' fundamental formal documents, such as strategies, reports, value declarations, mission statements, goals and philosophies. CSR formal maturity will be the measured construct.

- Basic underlying assumptions will refer to the company's motivation for CSR behavior and beliefs that the company has about the nature of the firm's responsibility towards the environment. CSR developmental maturity will be the measured construct.

- CSR maturity is reflected in the CSR process, the formal and developmental maturity. A higher maturity of practices in each of the three perspectives means a more advanced CSR implementation in the organization.

- The CSR maturity score allows qualifying the enterprise as using strategic, tactical or incidental CSR.

\subsection{Methods and Sample}

A CSR maturity model was used in order to assess the level of CSR practices of enterprises in Poland. Assessment of the three perspectives: CSR process maturity, CSR formal maturity and CSR developmental maturity contributed to the total CSR maturity evaluation of the company. The scores in each of these perspectives were normalized and brought to range $(0,1)$, and the total CSR maturity score was calculated as the average of the three:

CSR maturity score $=$ Average $($ CSR process maturity, CSR developmental maturity, CSR formal maturity $)$

The CSR maturity assessment was based on a qualitative content analysis of the documents present on the enterprises' websites. Content analysis is one of the qualitative research methods, alongside grounded theory, phenomenology or ethnography [93]. It is an approach allowing subjective interpretation of meanings and sense based on the content of data contained in communication such as text, image, interview, observations, or printed or electronic media [94]. This data, through coding and a systematic classification process, leads to finding patterns and regularities, and, as a result, better understanding of the phenomenon [95]. The content analysis method was used many times by researchers creating their own measures for the assessment of CSR practices in different countries $[55,61,96-100]$.

The purpose of the research was to assess the level of CSR maturity in enterprises, understood as the degree of their advancement as compared to the adopted model. During coding (as presented in Tables 3-5) and interpretation of data contained on the companies' websites, existing theories were referred to (e.g., Capability Maturity Model and CSR progression models). Therefore, it can be assumed that a theory-based deductive approach was used [101,102], meeting the requirements of a directed approach to content analysis [95].

During the CSR maturity evaluation, information contained in the following documents was analyzed:

- Companies' mission statements

- Codes of ethics

- Corporate governance declarations

- CSR reports and other CSR practice reports

- CSR strategies and other CSR practice declarations

- Prizes awarded to enterprises and membership in organizations

- Management systems implemented in companies

- Business strategies.

CSR practices were studied in 2016-2017. Ninety-three public listed companies were selected for the study (Appendix A), meeting the following requirements:

- $\quad$ Listed on the Warsaw Stock Exchange since at least 2007. 
- Represented nine sectors: construction, chemistry, developers, energy, IT, media, food, telecommunication, and banking.

- Listed in WIG industry indexes (between 2007 and 2013 continuously). The CSR maturity evaluation of enterprises in Poland was part of a larger research project covering also financial variables not used in this article and gathered between 2007 and 2013. The sample comprised of companies listed continuously in WIG industry indexes in this period.

All companies meeting the above requirements were included in the sample. Such a selection of companies (Table 1) ensured their diversity (nine sectors) and representativeness within the industries (continuous presence in the WIG industry index).

Table 1. Industries included in the sample.

\begin{tabular}{cc}
\hline Industry & Number of Companies \\
\hline Banking & 10 \\
Chemistry & 5 \\
Construction & 16 \\
Developers & 11 \\
Energy & 5 \\
Food & 13 \\
IT & 20 \\
Media & 8 \\
Telecommunication & 5 \\
\hline TOTAL & 93 \\
\hline
\end{tabular}

Source: Own work on the basis of WSE data.

There were 8 small companies (1-50 employees), 21 medium companies (51-250 employees) and 64 large companies (>250 employees) in the sample (Table 2).

Table 2. Company sizes included in the sample.

\begin{tabular}{ccc}
\hline & Company Size & Number of Companies \\
\hline Small & $1-50$ employees & 8 \\
\hline Medium & $51-250$ employees & 21 \\
\hline \multirow{3}{*}{ Large ( $>250$ employees) } & Medium big: $251-500$ employees & 14 \\
& Big: $501-5000$ employees & 34 \\
& Very big: $>5000$ employees & 16 \\
\hline & TOTAL & 93 \\
\hline
\end{tabular}

Source: Own work on the basis of WSE data.

\subsection{Measures: 3 Perspectives of CSR Maturity}

\subsubsection{CSR Process Maturity Measure}

CSR process maturity is aimed at investigating the level of CSR from the process perspective. The construction of the CSR process maturity measure was based on the CMM theory: Capability Maturity Model [26,27] and People Capability Maturity Model [28], which were specifically adapted for CSR.

The CMM model is a universal model used for analyzing the level of process maturity in organizations. Initially, it was invented for the IT industry and used for the assessment of the processes of software development on a five-level maturity scale from chaotic to strictly managed and optimized. It assumes that more mature (more optimized, stable and formalized) processes lead to better results, better projects and better financial decisions. The improvement of processes is also a way of reducing the company's risk. The more chaotic the process, the less predictable its results are and the higher the risk [26]. CMM describes five levels of process maturity: 
- Level 1: Initial: The process has not been identified yet, the actions are chaotic and ad hoc. The roles, duties and resources are not clearly specified yet.

- Level 2: Repeatable: The process is stabilized and repeatable. It creates predictable results, although it has not been formalized yet. Project management is implemented; budgeting and schedules are used.

- Level 3: Defined: The process has been defined and documented, roles were distributed, and resources were assigned. Specific codes of conduct and procedures have been developed.

- Level 4: Managed: measures (of effectiveness, quality, etc.) are used; the process is aimed at achieving company goals; it is strictly monitored and reported on an ongoing basis. The process is analyzed, and improvements are introduced.

- Level 5: Optimized: the organization is focused on a continuous improvement and optimization of the process by implementing innovations. It is regularly checked and updated.

According to the CMM concept, an organization becomes mature by moving from improvisation, ad hoc actions, unpredictable results, and unclear assessment criteria towards planning, observations, assessment and repeatability of processes.

The CMM model adapted to CSR also has a five-level scale (Table 3). The CSR maturity is accompanied by a growing predictability, repeatability and stability of processes leading to the realization of the CSR concept. In order to assess the CSR process maturity of the enterprise, a 1-5 scale was used (Table 3): from the initial, through repeatable, defined, and managed to the optimized levels. Next, the score awarded to the individual enterprises was normalized and brought to range $(0,1)$.

Table 3. CSR process maturity measure.

\begin{tabular}{ccl}
\hline Score (Points) & Level & \multicolumn{1}{c}{ Description } \\
\hline 1 & Initial & $\begin{array}{l}\text { Some or no CSR awareness. Considered but not implemented. } \\
\text { Repeatable }\end{array}$ \\
3 & Defined & $\begin{array}{l}\text { Formal CSR programs have been defined, but implementation is } \\
\text { inconsistent. } \\
\text { Methodological implementation of programs with adequate } \\
\text { measurement and management. } \\
\text { All CSR activities are monitored and managed for optimal } \\
\text { performance. Best practice. }\end{array}$ \\
\hline
\end{tabular}

Source: Own work on the basis of Capability Maturity Model [26,27] and Green ICT Capability Maturity Model [103].

Level 1 (initial) is characterized by the lack of CSR actions in the company and very low CSR awareness. At level 2 (repeatable), the enterprise introduces some ad hoc CSR activities, but the implementation is partial and random. The company has no CSR strategy, and, although some of their actions are repeatable, the discipline of their implementation is low, and the results are immeasurable and hard to predict.

At level 3 (defined), the company implements specific CSR programs with precisely defined processes. The processes are subject to control, but implementation is inconsistent.

At level 4 (managed), CSR activities and company's relationships with stakeholders are deliberately managed. The company develops measures which allow progress monitoring, employs a person responsible for CSR policy, and verifies the results of its CSR commitment.

At level 5 (optimized), all CSR actions and programs are planned, and their results are measured and managed. The company is a CSR leader, focused on improving its processes, and its actions are examples of CSR best practices. 


\subsubsection{CSR Formal Maturity Measure}

The CSR formal maturity is aimed at investigating the level of CSR commitment present in the company's values. The company's values are represented in formal communication like strategy, mission statement, goals and other declarations of a fundamental nature.

To assess the CSR formal maturity of enterprises, the companies' fundamental documents present on their websites were analyzed in searching for manifestations of CSR in formal communications. Also, the consistency of CSR declarations with business strategy were considered. The assessment was made with reference to the adopted model. The following documents were analyzed in particular: the company's mission statement, code of ethics, corporate governance declaration, CSR reports, CSR strategy, business strategy, documentation on quality systems and the membership of the companies in different CSR-supporting initiatives (e.g., Global Compact, GRI Global Reporting Initiative, Responsible Business Forum), CSR activity prizes, and presence in the RESPECT Index.

The CSR formal maturity measure assumed that the more explicitly CSR is referred to in the fundamental documents and the more the CSR-related declarations are integrated with the company's strategy, the more mature the CSR of the enterprise.

Table 4 shows a detailed description of the measures used in the study. Eight variables were analyzed and each of them was scored on a scale $(0,1)$. The additive score of a company was on $(0,8)$ scale. Next, the score given to individual enterprises was normalized and brought to range $(0,1)$.

Table 4. CSR formal maturity measure.

\begin{tabular}{|c|c|c|}
\hline Document & Score & Description \\
\hline \multirow{3}{*}{ Mission statement } & 0 & None/not available \\
\hline & 0.5 & Commitment to traditional stakeholders like customers and/or shareholders \\
\hline & 1 & Commitment to a wide group of stakeholders \\
\hline \multirow{3}{*}{ Code of conduct } & 0 & None \\
\hline & 0.5 & Brief values declaration \\
\hline & 1 & Extended code of conduct \\
\hline \multirow{4}{*}{$\begin{array}{l}\text { Corporate } \\
\text { governance } \\
\text { statement }^{1}\end{array}$} & 0 & No CG statement \\
\hline & 0.25 & Over 20 exclusions in CG statement \\
\hline & 0.5 & 10-20 exclusions in CG statement \\
\hline & 1 & Less than 10 exclusions in CG statement \\
\hline \multirow{3}{*}{ CSR report } & 0 & None/not available \\
\hline & 0.5 & Brief account \\
\hline & 1 & Extended report following guidelines i.e., GRI \\
\hline \multirow{3}{*}{ CSR strategy } & 0 & None/not available \\
\hline & 0.5 & Brief plan or declaration \\
\hline & 1 & Separate extended document \\
\hline \multirow{3}{*}{$\begin{array}{l}\text { CSR as part of the } \\
\text { corporate strategy }\end{array}$} & 0 & None \\
\hline & 0.5 & CSR as one of the elements of corporate strategy \\
\hline & 1 & CSR as an overriding perspective in corporate strategy \\
\hline \multirow{3}{*}{$\begin{array}{l}\text { Management } \\
\text { systems and } \\
\text { awards }\end{array}$} & 0 & None \\
\hline & 0.5 & Quality oriented management systems/awards (i.e., ISO 9000) \\
\hline & 1 & CSR oriented management systems/awards (i.e., ISO 14000) \\
\hline \multirow{3}{*}{$\begin{array}{c}\text { CSR } \\
\text { acknowledgment }\end{array}$} & 0 & None \\
\hline & 0.5 & Participation in CSR organizations or in RESPECT Index ${ }^{2}$ \\
\hline & 1 & Participation in CSR organizations and in RESPECT Index \\
\hline
\end{tabular}

According to the adopted model (Table 4), companies whose mission statements include commitment to a wide group of stakeholders represent a more mature CSR approach than companies who see their role and commitment more narrowly. 
Codes of ethics in companies with mature CSR exceed perfunctory declarations and take the form of developed documents with guidelines for execution.

Observance of corporate governance principles was measured with the number of exclusions the company declared from the "Warsaw Stock Exchange Listed Companies' Good Practices 2016". Since 2002, the WSE has been publishing sets of good corporate governance practices, and the listed companies have been obliged to disclose the exclusions from these recommendations. Fuller adoption of good corporate governance practices is a sign of a more mature CSR commitment.

CSR formal maturity is also reflected in the quality of CSR planning, disclosure and reporting. The more comprehensively the CSR activity is reported (e.g., with international report standards like GRI) and incorporated into the company's corporate strategy, the higher the CSR formal maturity score.

CSR values are also reflected in the diligence of implementing quality management systems oriented on improving ecological and social performance (e.g., ISO 14001 or ISO 26000), prizes received for achievements in the fields of quality, ethics and ecology, and the membership in CSR-supporting organizations (e.g., CSR Europe or Responsible Business Forum).

\subsubsection{CSR Developmental Maturity Measure}

The CSR developmental maturity measure is aimed at investigating the level of CSR commitment present in the philosophy and underlying assumptions of the enterprise. These assumptions refer to the company's motivation for CSR behaviour and beliefs about the nature of a firm's responsibility towards the environment.

The construction of CSR developmental maturity was based on the theory of Multiple Levels of CSR by van Marrevijk and Werre [17]. These authors founded their model on the theory of spiral dynamics created by psychologist Clare W. Graves [79] and developed by Don Beck [104] and Ken Wilber [80]. This theory describes the dynamics of the evolution of human consciousness and systems of values across the centuries, but also with reference to individuals. Graves points out a pattern of the evolution and widening of human consciousness and describes it using colors: So beige reflects the instinct, purple-magic and animism, red-impulsive and egocentric, blue-intentional and authoritarian, orange - strategic and achievement-oriented, green-egalitarian and socially oriented, yellow-integration, and teal-holistic. According to Graves, people do not ascend to higher and higher levels, but move up and down on a spiral, depending on their experience.

Marcel van Marrewijk and Marco Werre [17] adapted the spiral dynamics theory to the CSR context by creating a six-stage evolutionary model. This model shows different levels of CSR implementation, which are used by managers depending on their beliefs, context awareness and current systems of values. Each level contains and exceeds the previous one and is characterized by specific CSR practices.

To assess the enterprises' CSR developmental maturity, the narrative present in the company's documents and in management statements available in the public domain was analyzed in order to determine the motivation and beliefs behind the company's CSR involvement. A 1-6 scale was used for the assessment and categorization (Table 5); next the score given to the individual enterprises was normalized and brought to range $(0,1)$.

With the increase of CSR maturity, values presented by the company change from egoism to altruism, goals become more and more long-term and refer to a wider group of stakeholders, and motivation changes from instrumental to oriented to quality of life and creating shared value to multiple stakeholders. 
Table 5. CSR developmental maturity measure.

\begin{tabular}{ccl}
\hline Score & \multicolumn{1}{c}{ Level } & \multicolumn{1}{c}{ Description } \\
\hline 1 & $\begin{array}{c}\text { Pre-responsibility } \\
\text { (red) }\end{array}$ & $\begin{array}{l}\text { Egoism and loyalty of a business to itself. Lack of CSR activities unless } \\
\text { they are forced externally (strikes, external pressure, law) }\end{array}$ \\
\hline 2 & Compliance (blue) & $\begin{array}{l}\text { Business undertakes actions requiring social responsibility because of } \\
\text { the sense of obligation and within the framework required by law and } \\
\text { explicit social expectations. Ad hoc charity and sponsorship } \\
\text { involvement. }\end{array}$ \\
\hline 3 & Profit (orange) & $\begin{array}{l}\text { Business uses CSR activities to earn profit, thus strategically integrating } \\
\text { environmental, ethical, and social aspects of its operations. Triple } \\
\text { bottom line and CSR business case. }\end{array}$ \\
\hline 5 & Care (green) & $\begin{array}{l}\text { CSR initiatives go beyond what is required by law and what is the } \\
\text { business case, and results from the care for the planet and for people. } \\
\text { The motivation is human potential and sense of responsibility. }\end{array}$ \\
\hline 5 & Synergy (yellow) & $\begin{array}{l}\text { CSR activities are characterized by looking for win-win solutions and } \\
\text { for the harmony between what is environmental and social. Motivation } \\
\text { comes from the sense that sustainability is important. }\end{array}$ \\
\hline & & $\begin{array}{l}\text { Social responsibility permeates every aspect of the organization and the } \\
\text { business is oriented towards improving the quality of life of all beings. } \\
\text { Motivation for CSR comes from the awareness of a correlation between } \\
\text { all events and beings. }\end{array}$ \\
\hline
\end{tabular}

Source: Own work on the basis of multiple levels of CSR model [17] and spiral dynamics model [79,104].

According to the proposed model (Table 5), the first (red) level of CSR developmental maturity is "pre-responsibility". It is characterized by egoism and a company's loyalty to itself, resulting in the lack of CSR activities, unless forced (strikes, internal pressures, law). The next stage (blue) is "compliance". The company takes socially responsible actions motivated by the sense of obligation, law and explicit social expectations. At the orange ("profit") stage, the company carries out the CSR actions for profit, strategically integrating ecologic, ethical and social aspects in its business activity. The next stage (green) is motivated by care ("care"). CSR initiatives exceed the legal and economic necessity and result from the care of the planet and people. The fifth stage (yellow) is a stage of synergy, with a mature search for win-win solutions and harmony between what is economic, social and ecological. The motivation is driven by a belief that sustainability is important in itself. The highest level (teal) brings a holistic approach. Social responsibility penetrates through every aspect of the organization, and the company is oriented to improving the quality of life of all beings. The CSR motivation is driven by the awareness that all incidents and beings are interdependent. In this approach, every person and every organization is responsible for the welfare of others.

\subsubsection{Incidental, Tactical and Strategic CSR}

The scores in CSR process maturity, CSR formal maturity and CSR developmental maturity were normalized and brought to range $(0,1)$. Then the aggregated CSR maturity score was calculated as their average.

Scores achieved by enterprises allowed qualifying them to one of the groups: using incidental $\operatorname{CSR}(0,0.32)$, tactical CSR $(0.33,0.65)$ or strategic $\operatorname{CSR}(0.66,1)$. A description of the particular levels is given in Table 6. 
Table 6. CSR maturity model: incidental, tactical and strategic CSR in three perspectives (CSR process maturity, CSR formal maturity and CSR developmental maturity).

\begin{tabular}{|c|c|c|c|c|}
\hline CSR Maturity Level & Score & CSR Process Maturity & CSR Formal Maturity & CSR Developmental Maturity \\
\hline INCIDENTAL CSR & $0-0.32$ & $\begin{array}{l}\text { - Incidental or no CSR activity } \\
\text { - Little or no CSR awareness } \\
\text { - Choc implementation } \\
\text { - } \quad \text { No measure unpredictable procedures or control of the processes } \\
\text { Zero to few projects }\end{array}$ & $\begin{array}{l}\text { - } \text { Mission statement focusing on customers } \\
\text { - No code of ethics or explicit value declaration } \\
\text { - No CSR reporting } \\
\text { - } \quad \text { CSR not part of a business strategy } \\
\text { - Corporate governance practice in a minimal degree } \\
\quad \text { Declared quality orientation }\end{array}$ & $\begin{array}{l}\text { - Motivation: CSR undertaken out of duty and in order to comply } \\
\text { with legal and social requirements } \\
\text { - Activities: some charity responsiveness } \\
\text { - Values: order, correctness, justice }\end{array}$ \\
\hline TACTICAL CSR & $0.33-0.65$ & $\begin{array}{l}\text { - Defined and repeatable CSR activities } \\
\text { Basic management procedures, some documentation } \\
\text { and standardization } \\
\text { - Basic level of CSR monitoring } \\
\text { - Lots of CSR projects but no long-term strategy } \\
\text { or planning } \\
\text { Ad hoc resourcing, driven by enthusiasts, no top } \\
\text { management commitment }\end{array}$ & $\begin{array}{l}\text { - } \text { Mission statement focusing on customers } \\
\text { - } \quad \text { Explicit values declaration } \\
\text { - CSR policy } \\
\text { - } \quad \text { CSR norting } \\
\text { - } \\
\text { Mostly fort oflowing a corporiness strategy } \\
\text { Declared quality and sometimes CSR orientation }\end{array}$ & $\begin{array}{l}\text { - Motivation: profit through CSR implementation. business case } \\
\text { - Activities: integrating social, economic and ecological factors in } \\
\text { order to gain effectiveness } \\
\text { - Values: care for people, planet and profit }\end{array}$ \\
\hline STRATEGIC CSR & $0.66-1$ & $\begin{array}{l}\text { - Managed } \\
\text { - Methodical implementation of CSR, long-term goals } \\
\text { and planning } \\
\text { - Measurement, monitoring and analysis of CSR } \\
\text { effectiveness and impact } \\
\text { - Double-loop learning, optimization of the CSR } \\
\text { processes for stability and effectiveness } \\
\text { Best CSR practices, CSR leadership } \\
\text { - Full integration with company strategy, } \\
\text { clear commitment }\end{array}$ & 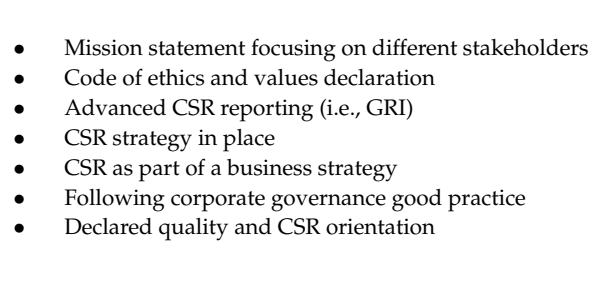 & $\begin{array}{l}\text { - Motivation: sustainability important in itself } \\
\text { - Activities: CSR permeating all the aspects of a company's } \\
\text { functioning and strategy. Triple bottom line. } \\
\text { - Values: wellbeing of all the stakeholders, shared value, } \\
\text { solidarity, harmony, interconnectedness, community }\end{array}$ \\
\hline
\end{tabular}


Companies using incidental CSR present low activity in this field. Few CSR projects are implemented in a random manner, chaotically and incidentally. The effectiveness of activities is not monitored, and they do not undergo long-term planning. They are undertaken with charitable motives or willingness to meet social expectations or legal requirements. Companies applying incidental CSR communicate it in the company's documents, like missions, values, strategy or reports, but only to a minor extent.

Companies applying tactical CSR manage this area in a considered and deliberate manner. CSR projects are largely planned and repeatable. The company is usually driven by instrumental motivation - the company assumes CSR will be a profitable investment. In its activities, it combines economic, environmental and social goals. CSR, however, does not constitute an important element in the strategy of the entire company.

The highest level of maturity is represented by companies applying strategic CSR. In these enterprises, CSR is a part of the business strategy and daily operations. CSR activities are planned, and their results are monitored and measured. The area is dynamically optimized and integrated in the company's business strategy. CSR is a constant perspective included in the company's daily routines; it is reflected in the mission statement, corporate values and company's code of ethics. The company has implemented high standards of CSR planning and reporting. The enterprise's CSR commitment is driven by normative motivation, coming from a company's values and a sense of solidarity with a wide range of stakeholders [105].

\section{Results and Interpretation}

To achieve the purpose of the research, being the diagnosis of CSR maturity of enterprises in Poland, a statistical analysis of gathered data was performed. It allowed giving answers to the following research questions:

1. Which level of CSR maturity—incidental, tactical or strategic — presented by the companies in Poland covered by the study? (Section 5.1)

2. What is the distribution of CSR maturity in the studied population and does the CSR maturity depend on a company's size and industry? (Section 5.2)

3. What is the level of CSR process maturity, CSR formal maturity and CSR developmental maturity, and what practices do the studied enterprises present? (Section 5.3)

\subsection{CSR Maturity Level of Enterprises in Poland: Incidental, Tactical and Strategic CSR}

Each of the companies was assessed for CSR process maturity, CSR formal maturity and CSR developmental maturity and was given an aggregate score in range $(0,1)$, where 0 means the lowest CSR maturity level, and 1 means the highest CSR maturity level.

According to the description in Table 7, the scores achieved by the companies were interpreted as incidental CSR (0-0.32), tactical CSR (0.33-0.65) or strategic CSR (0.66-1.0).

Table 7. CSR maturity level: incidental, tactical and strategic.

\begin{tabular}{cccc}
\hline CSR Maturity Level & CSR Maturity Score & No. of Companies & $\%$ \\
\hline Incidental CSR & $0-0.32$ & 44 & $\mathbf{\%}$ \\
Tactical CSR & $0.33-0.65$ & 29 & $\mathbf{3 1}$ \\
Strategic CSR & $0.66-1.0$ & 20 & $\mathbf{2 2}$ \\
Total & & 93 & $\mathbf{1 0 0}$ \\
\hline
\end{tabular}

Source: Own work.

The analysis of CSR maturity of enterprises in Poland shows a rather low level of advancement of the practice. Forty-seven percent of the sample (44 companies) apply incidental CSR, 30\% (29 companies) apply tactical CSR and 23\% (20 companies) are using strategic CSR. 
In the studied sample, nearly half of the companies use CSR on the basic level-this means a low activity in this field or taking only incidental and chaotic actions. The next $30 \%$ of the enterprises apply a more deliberate approach to CSR. In this case, the enterprises try to combine economic, social and environmental goals; the CSR projects are repeatable, but they are not of a strategic importance to the business. Twenty-two percent of the enterprises in the studied sample apply strategic CSR. It means planning, managing and optimization of this field of activity. Companies from this group follow extensive CSR reporting and disclosure practices, and CSR strategy is an important element of their business strategy, contributing to their competitive advantage.

The scores achieved indicate a rather low level of CSR maturity of enterprises in Poland. The distribution of answers (Figure 3) shows in fact that two-thirds of the studied companies achieve the maturity level below index $0.5(50 \%)$, and $15 \%$ of the companies present an extremely low level of CSR maturity, not exceeding index 0.16 . Only a small group of several percent of companies implement the CSR concept in their daily business activities in a mature way.

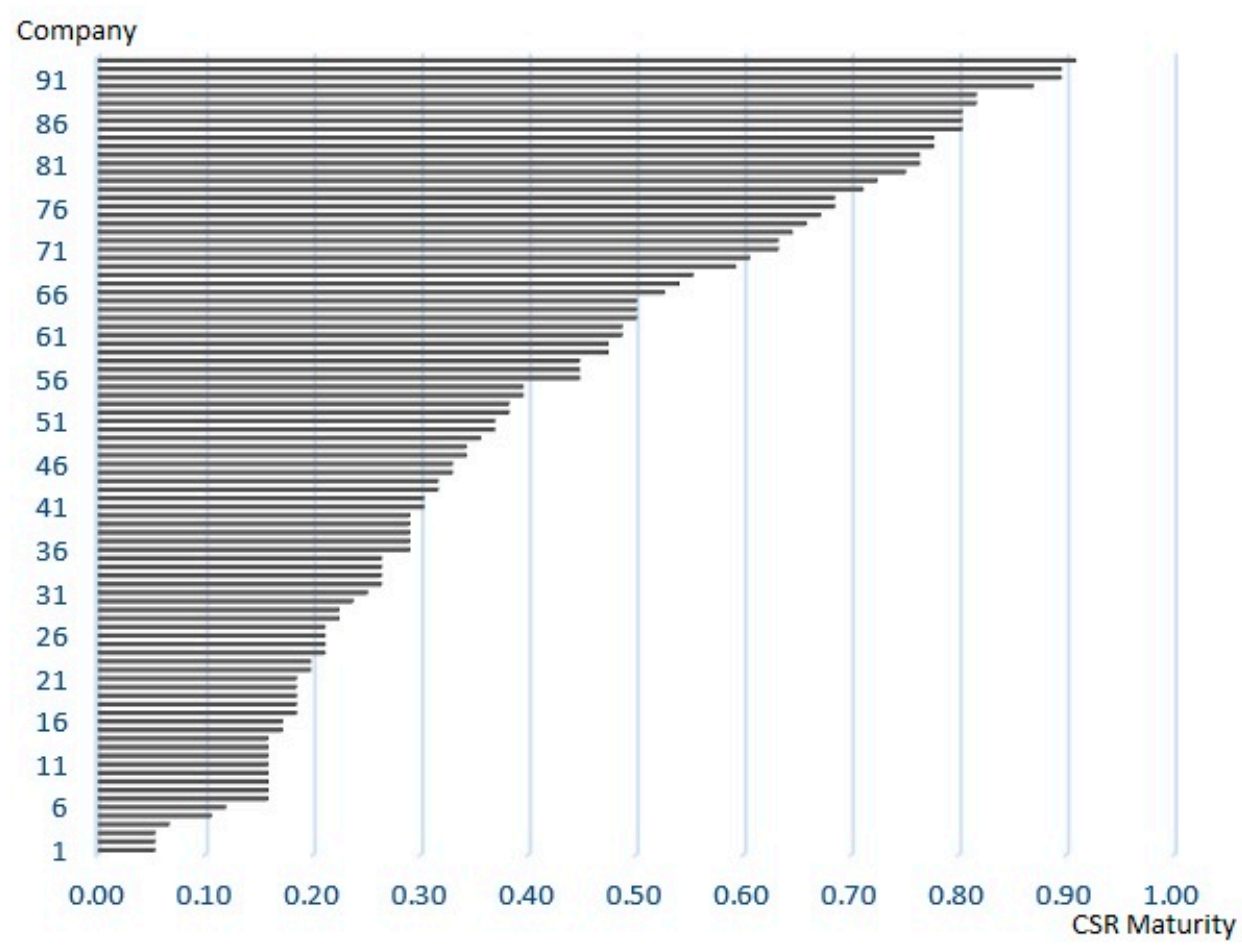

Figure 3. CSR maturity scores. Source: Own work.

\subsection{Factors Influencing CSR Maturity}

In order to answer the second research question: "What is the distribution of CSR maturity in the studied population and does the CSR maturity depend on a company's size and industry?", the following analysis was performed:

- Frequency distribution of CSR maturity results

- Correlation of CSR maturity and the company size

- Comparative analysis of CSR maturity average results for specific industries.

The CSR maturity frequency distribution chart (Figure 4) shows the asymmetry of the results. The chart is moderately positively skewed, which indicates uneven distribution of the feature in the studied population. A higher frequency of indications appears on the left side of the chart; significantly more companies show lower than average CSR maturity (skewness $=0.537$; mean $=0.41$; median $=0.34$; mode $=0.20$ ). 


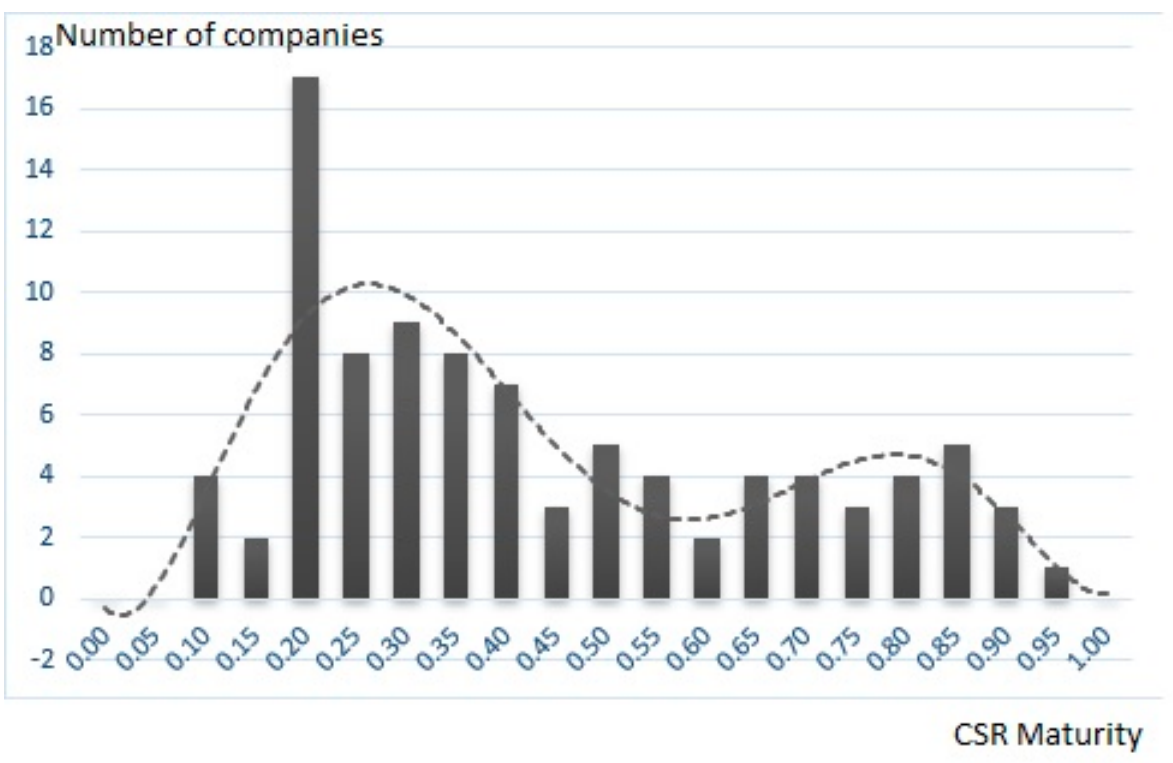

Figure 4. Frequency distribution of CSR maturity of the companies. Source: Own work.

The frequency distribution chart is also slightly bimodal-the trend line shows two peaks (Figure 4). The major mode is placed on the left side of the distribution curve and the minor mode is on the right. Such an image can indicate the existence of distinct groups of enterprises applying CSR with a use of different patterns. The right peak suggests that despite the left asymmetry of the chart, there is also an isolated group of enterprises displaying high CSR maturity.

The analysis of the 13 companies making up the right peak of the frequency distribution curve suggests some regularities concerning companies with the most mature CSR practices. From among the 13 isolated companies, 10 are companies listed in the RESPECT Index during the period covered by the study. Nine out of 13 are also very large companies, with more than 5000 employees, whereas the next four companies employ 700-5000 people. Five out of the 13 isolated companies were banks; this industry had the biggest representation in this group. RESPECT Index membership and a large company size seem to be conductive to higher CSR maturity results.

To verify how company size is related to CSR maturity, correlation between the CSR maturity score and the number of employees in the studied companies was analyzed (Table 8), as well as the distribution of the answers between the companies of different sizes (Table 9).

Table 8. Spearman correlation coefficients between CSR maturity and a company size.

\begin{tabular}{cc}
\hline CSR Maturity Score \\
\hline $\begin{array}{c}\text { Company size } \\
\text { (no. of employees) }\end{array}$ & $0.651 *$ \\
\hline$*$ dual correlation significance $=0.005 ; \mathrm{N}=90$. Source: Own work.
\end{tabular}

Table 9. CSR maturity level (incidental, tactical and strategic) in companies of different sizes.

\begin{tabular}{ccccc}
\hline \multirow{2}{*}{ CSR Maturity } & \multicolumn{3}{c}{ Company Size (No. of Employees) } & \multirow{2}{*}{ Total } \\
\cline { 2 - 4 } & Small (1-50) & Medium (51-250) & Large (>250) & \\
\hline Incidental CSR & 7 & 17 & 20 & $\mathbf{4 4}$ \\
Tactical CSR & 1 & 3 & 25 & $\mathbf{2 9}$ \\
Strategic CSR & 0 & 1 & 19 & $\mathbf{2 0}$ \\
Total & 8 & 21 & 64 & $\mathbf{9 3}$ \\
\hline
\end{tabular}

Source: Own work. 
A strong correlation $(p=0.651)$ between CSR maturity level and the company's size was found (Table 8). Average employment in a company implementing strategic CSR is 7874 employees; tactical CSR, 3960 employees; and incidental CSR, 715 employees. The company's size is the feature strongly determining the level of CSR implementation. Larger companies, with a wider group of stakeholders and a bigger environmental impact, consider CSR as a nondiscretionary strategic issue.

Table 9 presents data regarding the company size and CSR maturity level in the studied sample. From among 20 companies implementing strategic CSR, 19 are large companies. At the same time, 7 out of 8 small enterprises and 17 out of 20 medium-sized enterprises covered by the study implement incidental CSR. In the studied sample, the small and the medium enterprises are most homogeneous; with only a few exceptions, they implement incidental CSR. The most heterogeneous group are the large enterprises, where a similar number of companies implement incidental, tactical and strategic CSR. Such a distribution of the results suggests there is a significant gap in the maturity of CSR practices between the large companies in Poland and the small and medium ones. Small and medium companies present low CSR awareness and their practices are rather incidental.

According to the research, the enterprises' industry was another feature differentiating CSR maturity results (Table 10). Average CSR maturity levels for particular industries have been compared.

Table 10. CSR maturity level in different industries.

\begin{tabular}{cccc}
\hline CSR Maturity Level & Industry & $\begin{array}{c}\text { Industry Average CSR } \\
\text { Maturity Score }\end{array}$ & Coefficient of Variation \\
\hline Incidental CSR & Telecommunication & 0.26 & $120 \%$ \\
$(0-0.32)$ & IT & 0.28 & $47 \%$ \\
& Developers & 0.33 & $53 \%$ \\
Tactical CSR & Media & 0.33 & $70 \%$ \\
$(0.33-0.65)$ & Food & 0.40 & $51 \%$ \\
& Construction & 0.44 & $55 \%$ \\
Strategic CSR & Chemistry & 0.48 & $56 \%$ \\
$(0.66-1.0)$ & Banking & 0.64 & $42 \%$ \\
& Energy & 0.70 & $12 \%$ \\
\hline
\end{tabular}

Source: own work.

The most mature CSR practices in the studied sample (Table 10) are implemented by the banking and energy sector companies. Average results of companies in these industries place them on or close to the strategic level. IT and telecommunication industries show the lowest CSR maturity level (incidental CSR).

Particular sectors also have a different dispersion of CSR maturity results (Table 10). The most similar in terms of CSR standards are companies from the energy sector, whose coefficient of variation equals $12 \%$. In this industry, not only is the average CSR maturity level very high, but it is also the industry with the lowest variance, which indicates strong industry-wide standards for CSR behavior.

The largest dispersion of CSR maturity results is in the media and telecommunication sectors, where the coefficient of variation is $70 \%$ and $120 \%$ accordingly. These sectors include companies with very mature CSR practices as well as those who use CSR on a very basic level. In the remaining industries, the coefficient of variation is approximately 50\%. It means that in Poland there are no common industry standards for CSR practices. CSR initiatives are rather discretionary. Within the studied sample, the only exception is the energy sector. Results under discussion refer to the studied companies and cannot be treated as representative to all the companies in the aforementioned industries. More robust sector-specific conclusions would require a stricter industry focus of the research. 


\subsection{Three Perspectives of CSR Maturity}

The CSR maturity model proposed in this study referred to the three perspectives: CSR process maturity, CSR formal maturity and CSR developmental maturity. The scores achieved by enterprises in each of these perspectives are presented below (Table 11), together with a description of practices characteristic for enterprises in Poland.

Table 11. CSR process maturity in companies of different sizes.

\begin{tabular}{cccccc}
\hline \multirow{2}{*}{ CSR Process Maturity } & \multicolumn{3}{c}{ Number of Companies } & \multirow{2}{*}{$\%$} \\
\cline { 2 - 5 } & Small & Medium Large & Total & \\
\hline Initial & 7 & 16 & 21 & $\mathbf{4 4}$ & $\mathbf{4 7}$ \\
Repeatable & 1 & 4 & 10 & $\mathbf{1 5}$ & $\mathbf{1 6}$ \\
Defined & 0 & 1 & 17 & $\mathbf{1 8}$ & $\mathbf{1 9}$ \\
Managed & 0 & 0 & 9 & $\mathbf{9}$ & $\mathbf{1 0}$ \\
Optimized & 0 & 0 & 7 & $\mathbf{7}$ & $\mathbf{8}$ \\
\hline Total & 8 & 21 & 64 & $\mathbf{9 3}$ & $\mathbf{1 0 0}$ \\
\hline & Source: own work. & &
\end{tabular}

CSR process maturation means evolution from unplanned, chaotic and unstable CSR activities to ones which are predictable, managed, measured and optimized. Table 11 presents the CSR process maturity results achieved by enterprises. The CSR processes implemented by the studied companies are not advanced. Forty-seven percent of the enterprises are on the first "initial" level of process maturity, which means very little or no CSR awareness and no or next to no implementation. The next $35 \%$ of the companies implement CSR processes on a "repeatable" or "defined" level. It means that approximately one-third of the companies introduce CSR processes based on some recurrent activities, but those processes are fragmented and inconsistent, hence unstable and unpredictable. Ten percent of the companies manage CSR processes professionally, implementing them methodically and monitoring their results. They represent "the managed" level of maturity. The most advanced $8 \%$ of the companies optimize and improve the CSR processes, representing the best practices. It is worth noticing that, with a single exception, only large companies achieved the "defined", "managed" or "optimized" levels of CSR process maturity. Small or medium companies do not plan or manage CSR processes consciously.

The CSR formal maturity measure evaluates the presence of CSR commitment in the company's formal communication included in the mission statements, values, corporate governance declarations, CSR reports, and strategy. The more explicitly CSR is referred to in the fundamental documents and the more CSR-related declarations are integrated with the company's strategy, the higher the CSR formal maturity. The research results (Table 12) show a medium-low level of CSR formal maturity in the studied enterprises.

Nearly half of the studied companies (Table 12) show the lowest level of maturity by not publishing documents such as: mission statements, codes of conduct, CSR reports, or CSR strategies in any form. The only document that is more widely published (only $12 \%$ lack disclosure) is a corporate governance declaration, which is, however, obligatory for listed companies. Companies which do publish the aforementioned documents have most successfully included CSR in their codes of conduct (32\% highest scores) and mission statements (21\% highest scores), with strategy reports (16\% highest scores) and CSR strategies (13\% highest scores) showing a lower level of inclusion. 
Table 12. CSR formal maturity in companies of different sizes.

\begin{tabular}{|c|c|c|c|c|c|c|}
\hline \multirow{2}{*}{ Document } & \multirow{2}{*}{ Level of Practice } & \multicolumn{5}{|c|}{ Number of Companies } \\
\hline & & Small & Medium & Large & Total & $\%$ \\
\hline \multirow{5}{*}{$\begin{array}{l}\text { Corporate } \\
\text { governance } \\
\text { statement }\end{array}$} & No CG statement & 1 & 4 & 6 & 11 & 12 \\
\hline & Over 20 exclusions in CG statement & 1 & 3 & 5 & 9 & 10 \\
\hline & 10-20 exclusions in CG statement & 1 & 10 & 18 & 29 & 31 \\
\hline & Less than 10 exclusions in CG statement & 5 & 4 & 35 & 44 & 47 \\
\hline & Total & & & & 93 & 100 \\
\hline \multirow{4}{*}{ Mission statement } & None/not available & 7 & 11 & 24 & 42 & 45 \\
\hline & $\begin{array}{l}\text { Commitment to traditional stakeholders like } \\
\text { customers and/or shareholders }\end{array}$ & 1 & 8 & 23 & 32 & 34 \\
\hline & Commitment to a wide group of stakeholders & 0 & 2 & 17 & 19 & 21 \\
\hline & Total & & & & 93 & 100 \\
\hline \multirow{4}{*}{ Code of conduct } & None & 8 & 12 & 24 & 44 & 47 \\
\hline & Brief values declaration & 0 & 6 & 13 & 19 & 21 \\
\hline & Extended code of conduct & 0 & 3 & 27 & 30 & 32 \\
\hline & Total & & & & 93 & 100 \\
\hline \multirow{4}{*}{$\begin{array}{l}\text { CSR/Sustainability } \\
\text { report }\end{array}$} & None/not available & 7 & 17 & 27 & 51 & 55 \\
\hline & Brief account & 1 & 3 & 23 & 27 & 29 \\
\hline & Extended report following guidelines i.e., GRI & 0 & 1 & 14 & 15 & 16 \\
\hline & Total & & & & 93 & 100 \\
\hline \multirow{4}{*}{$\begin{array}{c}\text { CSR/Sustainability } \\
\text { strategy }\end{array}$} & None/not available & 7 & 16 & 24 & 47 & 50 \\
\hline & Brief plan or declaration & 1 & 5 & 28 & 34 & 37 \\
\hline & Separate extended document & 0 & 0 & 12 & 12 & 13 \\
\hline & Total & & & & 93 & 100 \\
\hline
\end{tabular}

Eighty-eight percent of the companies observe the obligation of the Warsaw Stock Exchange, stating that listed companies should disclose exclusions from the recommended corporate governance "Good Practices". Analysis of the corporate governance declarations indicates significant compliance of the CG practices with those recommended by the WSE. Forty-seven percent of the companies declare less than 10 exclusions. In this group, small companies compare very well with medium and large ones, being most compliant with WSE recommendations as a group. Transparency of governance in small enterprises is less complex than in bigger ones due to a smaller number of ownership and management relationship interdependencies. With regards to the other analyzed documents, like mission statements, codes of conduct, CSR reports, and strategies-small companies performed poorly due to a lack of disclosure.

The analysis of mission statements of the studied enterprises shows that $45 \%$ of them do not use this management tool at all. Among the companies which did not publish their mission statements were all but one of the small companies, more than half of the medium companies, and one-third of the large companies. One-third of all the companies refer to traditional stakeholders like customers and owners in their mission statements. A higher CSR awareness is shown by $21 \%$ of the companies, which addresses the needs for a wider group of stakeholders like the environment, the employees or the local community.

Forty-seven percent of the studied companies do not publish codes of conduct, $21 \%$ form only a brief declaration similar to the value code, and nearly one-third have extended and operationalized codes. There is no small company among them and only three medium companies.

Fifty percent of the companies do not create a CSR strategy, policy or a plan, and $55 \%$ do not report their CSR activities at all. In the studied sample, there are only several companies (13\%) that plan their CSR activities professionally and create separate documents regarding this subject, and $16 \%$ report their CSR performance in an extensive way, according to the international standards, such as GRI. The remaining one-third of the companies use intermediate solutions; they plan their CSR activity in the form of a short declaration and report it in the form of a brief basic account.

CSR developmental maturity is a measure which indicates what beliefs and motivations underly CSR actions. It refers to the CSR awareness of the companies. These beliefs and motivations can be deduced from the company's documents and statements of its management, when they give 
justification for taking on CSR activities. The more mature the CSR, the more altruistic the motivation and the more the company is focused on creating shared value for many stakeholders. According to the adopted model, instrumentally-motivated CSR means a lower maturity [17].

The research results indicate that for most companies, CSR activities are motivated either by the sense of obligation resulting from legal or social pressures, or by their own self-interest resulting from the belief that CSR could benefit the company (Table 13). Only $27 \%$ of the companies are motivated by care or a sense of solidarity with others.

Table 13. CSR developmental maturity in companies of different sizes.

\begin{tabular}{ccccccc}
\hline \multirow{2}{*}{ CSR Process Maturity } & & \multicolumn{3}{c}{ Number of Companies } & \multirow{2}{*}{$\%$} \\
\cline { 3 - 6 } & & Small & Medium & Large & Total & \\
\hline Pre-responsibility & Red & 1 & 2 & 3 & $\mathbf{6}$ & $\mathbf{6}$ \\
Compliance & Blue & 6 & 17 & 26 & $\mathbf{4 9}$ & $\mathbf{5 3}$ \\
Profit & Orange & 0 & 0 & 13 & $\mathbf{1 3}$ & $\mathbf{1 4}$ \\
Care & Green & 1 & 2 & 9 & $\mathbf{1 2}$ & $\mathbf{1 3}$ \\
Synergy & Yellow & 0 & 0 & 13 & $\mathbf{1 3}$ & $\mathbf{1 4}$ \\
Holism & Teal & 0 & 0 & 0 & $\mathbf{0}$ & $\mathbf{0}$ \\
\hline & Total & 8 & 21 & 64 & $\mathbf{9 3}$ & $\mathbf{1 0 0}$ \\
\hline \multicolumn{5}{c}{ Source: own work. }
\end{tabular}

Six percent of the studied companies (Table 13) are on the lowest pre-responsibility level ("red"), where CSR motivation is grounded in egoistic values and the loyalty of the business to itself. These companies do not take CSR actions unless motivated by strong external pressure.

The biggest group of $53 \%$ of the companies are motivated by compliance. At this "blue" level, companies are law-abiding and obligation-oriented. Their CSR activity is motivated by the will to observe legal standards and meet social expectations and usually comes down to taking on random charitable actions. This is the most common approach for enterprises in Poland.

The "orange" level means an economic motivation for CSR practices. Fourteen percent of the studied enterprises take on social responsibility due to financial reasons, expecting profits such as an improved reputation, investors' trust or clients' approval. Therefore, those companies try to integrate their economic, ecological and social goals.

Thirteen percent of the companies are on the "green" level-they implement CSR practices driven by care for others. CSR initiatives exceed legal, economic and social expectations, and are undertaken out of care for the planet and other stakeholders. This kind of narrative dominates in the communication of these companies.

The most advanced group of $14 \%$ of the studied companies were on the "yellow" level, called "the synergy". In this case, CSR involvement is motivated by a belief that sustainability is important in itself, regardless of profits it can bring to the company or of what others are expecting. Such companies value harmony and choose win-win solutions, reconciling the interests of many stakeholders.

None of the studied companies achieved the "teal" level, where social responsibility penetrates through every aspect of the organization and the company is oriented to improving the quality of life of all beings.

\section{Discussion}

The purpose of the present study was to diagnose the CSR maturity of enterprises in Poland, using a comprehensive, originally-developed diagnostic model. The model allowed the recognition of a strategic, tactical or incidental level of CSR commitment.

One of the main findings of the study of the 93 listed companies from nine sectors was that nearly half of the enterprises (47\%) use incidental CSR (ad hoc, unplanned and random or non-existent). The next 30\% implement tactical CSR (planned recurrent projects, instrumental motivation and inconsistent implementation). Twenty-three percent of the companies apply strategic CSR, in which case the 
concept penetrates through every aspect of the organization and is integrated with the company's business strategy.

Detailed analysis of the results leads to a conclusion that the companies in Poland present a certain CSR implementation structure. Approximately half of the companies do not engage in the CSR at all. Those are the companies in which CSR processes are not established. These companies do not publish their mission statements, values declarations or codes of conduct. They do not report CSR activities as they do not engage in CSR. This group comprises all the small companies from the sample, a majority of the medium companies, and one-third of the large companies. This is also a group of enterprises requiring the largest qualitative change of approach. The implementation of CSR in this case would require a shift in the way these companies view their responsibility towards the environment.

At the other extreme, there is a group of $20 \%$ of the companies representing the most mature CSR. They are the large companies (most of them employing over 5000 people) which have implemented the best CSR practices. They manage their CSR activities professionally, through planning, monitoring and reporting, and their CSR strategy is coupled with their business strategy. They are the companies which made a conscious decision to build a reputation of being socially responsible. Most of them belong to the RESPECT Index-the social responsibility index of the Warsaw Stock Exchange. This group comprises many representatives from the banking and energy sectors. However, dispersion of the results indicates that in Poland there are no common industry standards for CSR practices. The only exception in the studied example is the energy sector. CSR practices in Poland are still more of an individual choice of a company than an industry norm.

Approximately one-third of the studied companies undertake some CSR activities and take responsibility for their impact on the environment, but their practices are still immature. Actions, usually of a philanthropic nature, although planned and sometimes recurrent, are not part of the CSR policy or business strategy and are not considered permanent strategic projects.

The literature review and the empirical research regarding the CSR maturity of enterprises in Poland leads to the conclusion, that although Poland has significantly improved its CSR institutional context in the last 20 years, the level of CSR practices in the enterprises is still rather low.

To support the advancement of CSR commitment of enterprises in Poland, special attention should be paid to:

- Popularization of the CSR concept in small and medium enterprises, which currently demonstrates the lowest CSR maturity.

- Supporting CSR industry standards. Currently most sectors in Poland do not have widely accepted CSR norms.

- $\quad$ Promoting the best CSR practices of the leaders and the CSR maturity model.

- Holistic CSR education, directed at implementing CSR at all three levels of organizational culture: beliefs, values and artifacts. In the area of beliefs, enterprises should be encouraged to reconsider their role and responsibility to the environment. In the area of values, companies should be educated on how to include CSR philosophy in all their fundamental documents i.e., mission statements, codes of conduct, or CSR and business strategies. With regards to artifacts, the education should focus on how to build mature, stable and predictable CSR processes and routines.

The presented studies are not free from limitations. The conceptual model of CSR maturity, which was used for diagnosis of the enterprises, is highly aggregated. The measure comprises three perspectives: CSR process maturity, CSR formal maturity and CSR developmental maturity. On the one hand, such a complex measure allows a comprehensive assessment, on the other, however, the aggregation of the measure makes interpretation difficult.

Also, the qualitative content analysis of the companies' websites has its own limitations. The analysis of keywords and specific content published on the websites can be affected by interpretation errors resulting from subjective assignment of codes and categories by the researcher. 
The research sample, although diverse in terms of company size and sector affiliation, is not representative of Poland. The results should be treated with caution and it should be emphasized that they refer to the sample rather than to the general population of enterprises in Poland. Generalization for the entire population would require extension of the research.

Funding: The research has been financed by the National Science Centre in Poland as a research project No. 2012/07/D/HS4/00531. The project has been financed by the Ministry of Science and Higher Education in Poland under the programme "Regional Initiative of Excellence" 2019-2022 project number 015/RID/2018/19 total funding amount 10721 040,00 PLN".

Acknowledgments: I would like to thank the Reviewers for their valuable input and helping me improve the manuscript.

Conflicts of Interest: The author declares no conflict of interest. The founding sponsors had no role in the design of the study; in the collection, analyses, or interpretation of data; in the writing of the manuscript, and in the decision to publish the results.

\section{Appendix A}

Table A1. List of companies.

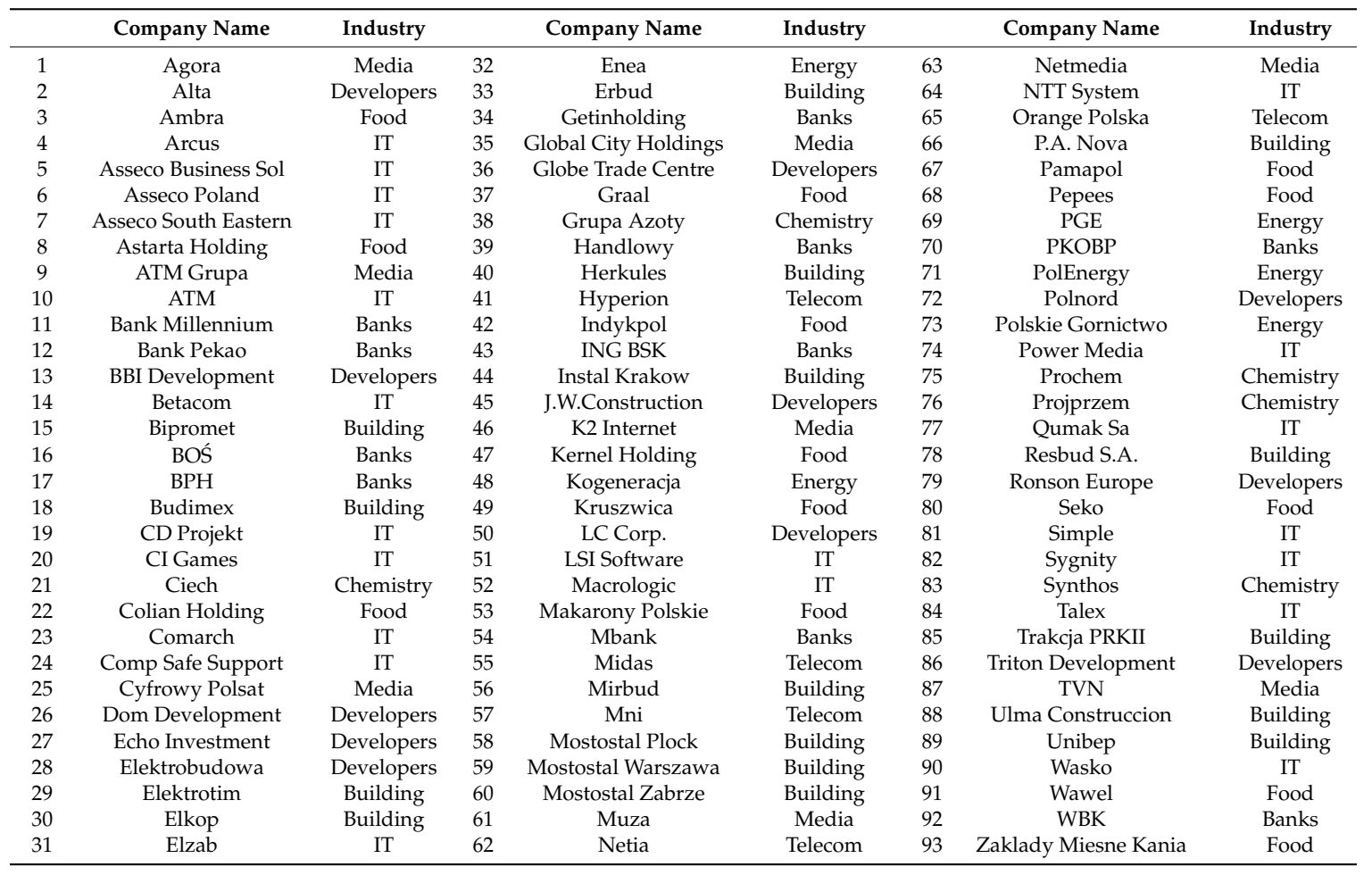

\section{References}

1. Społeczna Odpowiedzialność Biznesu: Fakty a Opinie. CSR Oczami Dużych $i$ Średnich firm w Polsce; Forum Odpowiedzialnego Biznesu, KPMG: Warszawa, Poland, 2014; Available online: http://odpowiedzialnybiznes.pl/wp-content/uploads/2014/11/Raport-Spo\%C5\%82ecznaodpowiedzialno\%C5\%9B\%C4\%87-biznesu-fakty-a-opinie-KPMG-FOB-20141.pdf (accessed on 1 January 2019).

2. Matuszak, Ł.; Różańska, E. CSR Disclosure in Polish-Listed Companies in the Light of Directive 2014/95/EU Requirements: Empirical Evidence. Sustainability 2017, 9, 2304. [CrossRef]

3. Dyduch, J.; Krasodomska, J. Determinants of Corporate Social Responsibility Disclosure: An Empirical Study of Polish Listed Companies. Sustainability 2017, 9, 1934. [CrossRef] 
4. Wirth, H.; Kulczycka, J.; Hausner, J.; Koński, M. Corporate Social Responsibility: Communication about social and environmental disclosure by large and small copper mining companies. Resour. Policy 2016, 49, 53-60. [CrossRef]

5. Szczepankiewicz, E.; Mućko, P. CSR Reporting Practices of Polish Energy and Mining Companies. Sustainability 2016, 8, 126. [CrossRef]

6. Pactwa, K.; Woźniak, J. Environmental reporting policy of the mining industry leaders in Poland. Resour. Policy 2017, 53, 201-207. [CrossRef]

7. Fijalkowska, J.; Macuda, M. CSR Reporting Practices in Poland. In Corporate Social Responsibility in Poland. Strategies, Opportunities and Challenges; Długopolska-Mikonowicz, A., Przytuła, S., Stehr, C., Eds.; Springer: Cham, Switzerland, 2019; pp. 195-213. ISBN 978-3-030-00439-2.

8. Rojek-Nowosielska, M. Społeczne Odpowiedzialność Przedsiębiorstw. Model-Diagnoza-Ocena; Wydawnictwo Uniwersytetu Ekonomicznego we Wrocławiu: Wrocław, Poland, 2017; ISBN 978-83-7695-655-8.

9. Wołczek, P. Development of the CSR Concept in Poland-Progress or Stagnation? Res. Pap. Wroctaw Univ. Econ. 2015, 387, 200-214. [CrossRef]

10. Frederick, W.C. From CSR1 to CSR2: The Maturing of Business and Society Thought; Working Paper 279; Graduate School of Business, University of Pittsburgh: Pittsburgh, PA, USA, 1978.

11. Frederick, W.C. Toward CSR3: Why ethical analysis is indispensable and avoidable in ethical affairs. Calif. Manag. Rev. 1986, 28, 12-25. [CrossRef]

12. Frederick, W.C. Moving to CSR4. Bus. Soc. Rev. 1998, 37, 40-59. [CrossRef]

13. Carroll, A.B. The pyramid of corporate social responsibility: Toward the moral management of organizational stakeholders. Bus. Horizons 1991, 34, 39-48. [CrossRef]

14. Porter, M.E.; Kramer, M.R. The Competitive Advantage of Corporate Philanthropy. Harv. Bus. Rev. 2002, 80, 57-68.

15. Porter, M.E.; Kramer, M.R. Strategy and society: The link between competitive advantage and corporate social responsibility. Harv. Bus. Rev. 2006, 84, 78-92.

16. Porter, M.E.; Kramer, M.R. Creating Shared Value. Harv. Bus. Rev. 2011, 89, 62-77.

17. van Marrewijk, M.; Werre, M. Multiple Levels of Corporate Sustainability. J. Bus. Ethics 2003, 44, 107-119. [CrossRef]

18. Zadek, S. The Path to Corporate Responsibility. Harv. Bus. Rev. 2004, 82, 125-132.

19. Mirvis, P.; Googins, B. Stages of Corporate Citizenship. Calif. Manag. Rev. 2006, 48, 104-126. [CrossRef]

20. Jones, T.M.; Felps, W.; Bigley, G. Ethical theory and stakeholder-related decisions: The role of stakeholder culture. Acad. Manag. Rev. 2007, 32, 137-155. [CrossRef]

21. Baumgartner, R.J.; Ebner, D. Corporate sustainability strategies: Sustainability profiles and maturity levels. Sustain. Dev. 2010, 18, 76-89. [CrossRef]

22. Visser, W. The Future of CSR: Towards Transformative CSR or CSR 2.0; Kaleidoscope Futures Paper Series; Kaleidoscope Futures: Cambridge, UK, 2012; 17p.

23. Visser, W. CSR 2.0.-Transforming Corporate Sustainability and Responsibility; Springer: London, UK, 2014; ISBN 978-3-642-40874-8.

24. Martinuzzi, A.; Krumay, B. The Good, the Bad, and the Successful-How Corporate Social Responsibility Leads to Competitive Advantage and Organizational Transformation. J. Chang Manag. 2013, 13, 424-443. [CrossRef]

25. Witek-Crabb, A. Maturity of Strategic Management in Organizations. Oeconomia Copernicana 2016, 7, 669-682. [CrossRef]

26. Persse, J.R. Implementing the Capability Maturity Model; Wiley Computer Publishing: New York, NY, USA, 2001.

27. Paulk, M.C.; Curtis, B.; Chrissis, M.B.; Weber, C.V. Capability Maturity Model for Software, Version 1.1; Technical Report; Software Engineering Institute: Pittsburgh, PA, USA, 1993.

28. Curtis, B.; Hefley, B.; Miller, S. People Capability Maturity Model (P-CMM) Version 2.0, 2nd ed.; Technical Report; Software Engineering Institute: Pittsburgh, PA, USA, 2009.

29. Schein, E.H. Coming to a New Awareness of Organizational Culture. Sloan Manag. Rev. 1984, 12, 3-16.

30. Milanovic, B. Social Costs of the Transition to Capitalism: Poland, 1990-91; Policy Research Working Paper; Series 1165; The World Bank: Washington, DC, USA, 1993. 
31. Gomułka, S. Poland's economic and social transformation 1989-2014 and contemporary challenges. Cent. Bank Rev. 2016, 16, 19-23. [CrossRef]

32. Strategia Zrównoważonego Rozwoju Polski do 2025. Available online: http://www.access.zgwrp.org. $\mathrm{pl} /$ materialy/dokumenty/StrategiaZrownowazonegoRozwojuPolski/wprowadzenie.html (accessed on 1 January 2019).

33. EU Green Paper: Promoting a European Framework for Corporate Social Responsibility; European Commission: Brussels, Belgium, 2001.

34. United Nations Development Programme. Corporate Social Responsibility in Poland. Baseline Study. 2007. Available online: https://ngoteka.pl/bitstream/handle/item/85/spoleczna_odpowiedzialnosc_biznesu. pdf?sequence=1 (accessed on 1 January 2019).

35. Grabara, J.; Dura, C.; Driga, I. Corporate social responsibility awareness in Romania and Poland: A comparative analysis. Econ. Sociol. 2016, 9, 344-359. [CrossRef]

36. Gruszewska, E.; Wakuluk, I. Napływ bezpośrednich inwestycji zagranicznych do Polski-szanse rozwoju, scenariusze naprawcze. Zarzadzanie i Finanse 2012, 1, 263-272.

37. Dyczkowska, J.; Krasodomska, J.; Michalak, J. CSR in Poland: Institutional context, legal framework and voluntary initiatives. Account. Manag. Inf. Syst. 2016, 15, 206-254.

38. Realizacja Celów Zrównoważonego Rozwoju w Polsce-Raport 2018. Raport Przyjęty przez Radę Ministrów 05.06.2018. Available online: https://www.mpit.gov.pl/media/54729/Raport_VNR_wer_do_uzgodnien_ 20180330.pdf (accessed on 1 January 2019).

39. Strategia na rzecz Odpowiedzialnego Rozwoju. Accepted by the Council of Ministers on 14.02.2017. Available online: https:/ / www.miir.gov.pl/media/48672/SOR.pdf (accessed on 1 January 2019).

40. Ustawa z Dnia 15 Grudnia 2016 r. o Zmianie Ustawy o Rachunkowo'sci [Amended Act to Polish Accounting Act from 15 of December 2016], Dz. U. 2017. Poz. 61. Available online: http://dziennikustaw.gov.pl/du/ 2017/61/D2017000006101.pdf (accessed on 20 December 2018).

41. European Union Directive 2014/95/EU of the European Parliament and of the Council of 22 October 2014 Amending Directive 2013/34/EU as Regards Disclosure of Non-Financial and Diversity Information by Certain Large Undertakings and Groups. 2014. Available online: http:/ / eur-lex.europa.eu/legal-content/ EN/TXT/PDF/?uri=OJ:L:2014:330:FULL\&from=EN (accessed on 10 December 2018).

42. Sroka, R. Raportowanie Niefinansowe: Wymagania Ustawy o Rachunkowości a Praktyka Rynkowa. Wyniki Analizy ESG Spótek w Polsce 2017; SEG, GES, E\&Y: Warszawa, Poland, 2017; ISBN 978-83-946600-4-8.

43. Sustainability Disclosure Database. Available online: http://database.globalreporting.org (accessed on 10 December 2018).

44. Społeczna Odpowiedzialność Biznesu w Polskich Realiach. Teoria a Praktyka. Raport Monitoring Społecznej Odpowiedzialności Największych Polskich Firm; Fundacja CentrumCSR.pl: Warszawa, Poland, 2015.

45. Campbell, J.L. Why would corporations behave in socially responsible ways? An institutional theory of corporate social responsibility. Acad. Manag. Rev. 2007, 32, 946-967. [CrossRef]

46. Yang, X.; Rivers, C. Antecedents of CSR practices in MNCs' subsidiaries: A stakeholder and institutional perspective. J. Bus. Ethics 2009, 86, 155-169. [CrossRef]

47. Aguilera, R.V.; Rupp, D.; Williams, C.; Ganapathi, J. Putting the S Back in Corporate Social Responsibility: A Multi-Level Theory of Social Change in Organizations. Acad. Manag. Rev. 2007, 32, 836-863. [CrossRef]

48. Matten, D.; Moon, J. "Implicit" and "Explicit" CSR: A Conceptual Framework for a Comparative Understanding of Corporate Social Responsibility. Acad. Manag. Rev. 2008, 33, 404-424. [CrossRef]

49. Peng, Y.; Dashdeleg, A.; Lin Chih, H. National Culture and Firm's CSR Engagement: A Cross-Nation Study. J. Mark. Manag. 2014, 5, 38-49.

50. Ali, W.; Frynas, J.G.; Mahmood, Z. Determinants of Corporate Social Responsibility (CSR) Disclosure in Developed and Developing Countries: A Literature Review. Corp. Soc. Responsib. Environ. Manag. 2017, 24, 273-294. [CrossRef]

51. Cowen, S.S.; Ferreti, L.B.; Parker, L.D. The impact of corporate characteristics on responsibility disclosure: A typology and frequency-based analysis. Account. Organ. Soc. 1987, 12, 111-122. [CrossRef]

52. Deegan, C.; Gordon, B. A study of the environmental disclosure practices of Australian corporations. Account. Bus. Res. 1996, 26, 187-199. [CrossRef] 
53. Holder-Webb, L.; Cohen, J.R.; Nath, L.; Wood, D. The supply of corporate social responsibility disclosures among U.S. firms. J. Bus. Ethics 2008, 84, 497-527. [CrossRef]

54. Meek, G.K.; Roberts, C.B.; Gray, A.J. Factors influencing voluntary annual report disclosures by US, UK and continental European multinational corporations. J. Int. Bus. Stud. 1995, 26, 555-572. [CrossRef]

55. Gamerschlag, R.; Möller, K.; Verbeeten, F. Determinants of voluntary CSR disclosure: Empirical evidence from Germany. Rev. Manag. Sci. 2011, 5, 233-2662. [CrossRef]

56. Linnenluecke, M.K.; Griffiths, A. Corporate sustainability and organizational culture. J. World Bus. 2010, 45, 357-366. [CrossRef]

57. Hofstede, G. Culture and Organizations. Int. Studies Manag. Organ. 1980, 10, 15-41. [CrossRef]

58. Roberts, R.W. Determinants of corporate social responsibility disclosure: An application of stakeholder theory. Account. Org. Soc. 1992, 17, 595-612. [CrossRef]

59. Siregar, S.V.; Bachtiar, Y. Corporate social reporting: Empirical evidence from Indonesia Stock Exchange. Int. J. Islamic Middle Eastern Financ. Manag. 2010, 3, 241-252. [CrossRef]

60. Witek-Crabb, A. Sustainable Strategy-A Research Report on Sustainability Practices in Polish Enterprises. In Proceedings of the 32nd International Business Information Management Association Conference IBIMA, Seville, Spain, 15-16 November 2018; Soliman, K.S., Ed.; pp. 6087-6100.

61. Ho, L.C.J.; Taylor, M.E. An empirical analysis of triple bottom-line reporting and its determinants: Evidence from the United States and Japan. J. Int. Financ. Manag. Account. 2007, 18, 123-150. [CrossRef]

62. Brammer, S.; Millington, A. Firm Size, Organizational Visibility and Corporate Philanthropy: An Empirical Analysis. Bus. Ethics Eur. Rev. 2006, 15, 6-18. [CrossRef]

63. Mohr, L.A.; Webb, D.J.; Harris, K.E. Do Consumers Expect Companies to be Socially Responsible? The Impact of Corporate Social Responsibility on Buying Behavior. J. Consum. Affairs 2001, 35, 45-72. [CrossRef]

64. McWilliams, A.; Siegel, D. Corporate Social Responsibility: A Theory of the Firm Perspective. Acad. Manag. Rev. 2001, 26, 117-127. [CrossRef]

65. Cho, C.H.; Roberts, R.W.; Patten, D.M. The language of US corporate environmental disclosure. Account. Organ. Soc. 2009. [CrossRef]

66. Cormier, D.; Gordon, I.M. An examination of social and environmental reporting strategies: Determinants, costs and benefits. Account. Audit. Accoun. 2001, 14, 587-616. [CrossRef]

67. Watts, R.L.; Zimmermann, J.L. Positive accounting theory: A ten year perspective. Account. Rev. 1990, 65, 131-156.

68. Glavas, A. Corporate social responsibility and organizational psychology: An integrative review. Front. Psychol. 2016, 7, 144. [CrossRef]

69. Rupp, D.E.; Ganapathi, J.; Aguilera, R.V.; Williams, C.A. Employee reactions to corporate social responsibility: An organizational justice framework. J. Organ. Behav. 2006, 27, 537-543. [CrossRef]

70. Rupp, D.E.; Mallory, D.B. Corporate social responsibility: Psychological, person-centric, and progressing. Ann. Rev. Organ. Psychol. 2015, 2, 211-236. [CrossRef]

71. Aguinis, H.; Glavas, A. What we know and don't know about corporate social responsibility: A review and research agenda. J. Manag. 2012, 38, 932-968. [CrossRef]

72. Gond, J.P.; El Akremi, A.; Swaen, V.; Babu, N. The psychological microfoundations of corporate social responsibility: A person-centric systematic review. J. Organ. Behav. 2017, 38, 225-246. [CrossRef]

73. Greening, D.W.; Gray, B. Testing a model of organizational response to social and political issues. Acad. Manag. J. 1994, 37, 467-498.

74. Muller, A.; Kolk, A. Extrinsic and intrinsic drivers of corporate social performance: Evidence from foreign and domestic firms in Mexico. J. Manag. Studies 2010, 47, 1-26. [CrossRef]

75. Weaver, G.R.; Treviño, L.K.; Cochran, P.L. Integrated and decoupled corporate social performance: Management commitments, external pressures, and corporate ethics practices. Acad. Manag. J. 1999, 42, 539-552. [CrossRef]

76. Bansal, P. From issues to actions: The importance of individual concerns and organizational values in responding to natural environmental issues. Organ. Sci. 2003, 14, 510-527. [CrossRef]

77. Stevens, J.M.; Steensma, H.K.; Harrison, D.A.; Cochran, P.L. Symbolic or substantive document? The influence of ethics codes on financial executives' decisions. Strategy Manag. J. 2005, 26, 181-195. [CrossRef] 
78. Witek-Crabb, A. Evolutionary models of CSR—Between the paradigms of moral and economic value creation. In Proceedings of the EURAM Annual Conference: Making Knowledge Work, Glasgow, UK, 21-24 June 2017.

79. Graves, C.W. Human Nature Prepares for a Momentous Leap. Futurist 1974, 8, $72-87$.

80. Wilber, K. A Theory of Everything: An Integral Vision for Business, Politics, Science and Spirituality; Shambhala Publications, Inc.: Boston, MA, USA, 2000; ISBN 978-1-57062-724-8.

81. Halme, M.; Laurila, J. Philanthropy, Integration or Innovation? Exploring the Financial and Societal Outcomes of Different Types of Corporate Responsibility. J. Bus. Ethics 2009, 84, 325-339. [CrossRef]

82. Pinkston, T.S.; Carroll, A.B. A retrospective examination of CSR orientations: Have they changed? J. Bus. Ethics 1996, 15, 199-206. [CrossRef]

83. Maon, F.; Lindgreen, A.; Swaen, V. Organizational Stages and Cultural Phases: A critical Review and a Consolidative Model of Corporate Social Responsibility Development. Int. J. Manag. Rev. 2010, 12, 20-38. [CrossRef]

84. de Woot, P. Should Prometheus Be Bound; Palgrave Macmillan: New York, NY, USA, 2005; ISBN 978-0-230-57812-8.

85. Mitchell, R.K.; Agle, B.R.; Wood, D.J. Toward a Theory of Stakeholder Identification and Salience: Defining the Principle of Who and What Really Counts. Acad. Manag. Rev. 1997, 22, 853-886. [CrossRef]

86. Frooman, J. Socially Irresponsible and Illegal Behavior and Shareholder Wealth. A Meta-Analysis of Event Studies. Bus. Soc. 1997, 36, 221-249. [CrossRef]

87. Griffin, J.J.; Mahon, J.F. The Corporate Social Performance and Corporate Financial Performance Debate. Twenty-Five Years of Incomparable Research. Bus. Soc. 1997, 36, 5-31. [CrossRef]

88. Key, S.; Popkin, S.J. Integrating ethics into the strategic management process: Doing well by doing good. Manag. Decis. 1998, 36, 331-338. [CrossRef]

89. Waddock, S.A.; Graves, S.B. The Corporate Social Performance-Financial Performance Link. Strategy Manag. J. 1997, 18, 303-319. [CrossRef]

90. Hillman, A.J.; Keim, G.D. Shareholder Value, Stakeholder Management, and Social Issues: What's the Bottom Line? Strategy Manag. J. 2001, 22, 125-139. [CrossRef]

91. Surroca, J.; Tribo, J.A.; Waddock, S. Corporate responsibility and financial performance: The role of intangible resources. Strategy Manag. J. 2010, 31, 463-490. [CrossRef]

92. Schein, E. Organizational Culture and Leadership; Jossey Bass: San Francisco, CA, USA, 1985; ISBN 978-0875896397.

93. Burnard, P. Interpreting text: An alternative to some current forms of textual analysis in qualitative research. Soc. Sci. Health 1995, 1, 236-245.

94. Kondracki, N.L.; Wellman, N.S. Content analysis: Review of methods and their applications in nutrition education. J. Nutr. Educ. Behav. 2002, 34, 224-230. [CrossRef]

95. Hsieh, H.; Shannon, S.E. Three Approaches to Qualitative Content Analysis. Qual. Health Res. 2005, 1277-1288. [CrossRef]

96. Bayoud, N.S.; Kavanagh, M.; Slaughter, G. Factors influencing levels of corporate social responsibility disclosure by Libyan firms: A mixed study. Int. J. Econ. Financ. 2012, 4, 13-29. [CrossRef]

97. Rahman, N.H.W.A.; Zain, M.M.; Al-Haj, N.H.Y.Y. CSR disclosures and its determinants: Evidence from Malaysian government link companies. Soc. Responsib. J. 2011, 7, 181-201. [CrossRef]

98. Hussainey, K.; Elsayed, M.; Abdel Razik, M.A. Factors affecting corporate social responsibility disclosure in Egypt. Corp. Ownersh. Control J. 2011, 8, 432-443. [CrossRef]

99. Rouf, A. The corporate social responsibility disclosure: A study of listed companies in Bangladesh. Bus. Econ. Res. J. 2011, 2, 19-32.

100. Tagesson, T.; Blank, V.; Broberg, P.; Collin, S.O. What explains the extent and content of social and environmental disclosures on corporate web sites: A study of social and environmental reporting in Swedish listed corporations. Corp. Soc. Responsib. Environ. Manag. 2009, 16, 352-364. [CrossRef]

101. Potter, W.J.; Levine-Donnerstein, D. Rethinking validity and reliability in content analysis. J. Appl. Commun. Res. 1999, 27, 258-284. [CrossRef]

102. Berg, B.L. Qualitative Research Methods for the Social Sciences; Allyn and Bacon: Boston, MA, USA, 2001; ISBN 13 978-0134202136.

103. Philipson, G. A Green ICT Framework: Understanding and Measuring Green ICT; Connection Research Services Pty Ltd.: St Leonards, Australia, 2010; ABN 47092657513. 
104. Beck, D.; Cowan, C. Spiral Dynamics: Mastering Values, Leadership and Change; Wiley-Blackwell: Malden, MA, USA, 1996; ISBN 155786-940-5.

105. Witek-Crabb, A. CSR Versus Business Financial Sustainability of Polish Enterprises. In Corporate Social Responsibility in Poland. Strategies, Opportunities and Challenges; Długopolska-Mikonowicz, A., Przytuła, S., Stehr, C., Eds.; Springer: Cham, Switzerland, 2019; pp. 43-58. ISBN 978-3-030-00439-2. 